\title{
FAKTOR-FAKTOR YANG MEMPENGARUHI PERSISTENSI LABA (Studi Kasus pada Perusahaan Property dan Real Estate yang Terdaftar di Bursa Efek Indonesia Tahun 2013-2015)
}

\author{
Risma Nuraeni, Sri Mulyati, Trisandi Eka Putri \\ STIE Sutaatmadja (STIESA) Subang
}

\begin{tabular}{|c|c|}
\hline INFO ARTIKEL & ABSTRAK/ABSTRACK \\
\hline $\begin{array}{l}\text { Histori Artikel : } \\
\text { Tgl Masuk : } 29 \text { Nov. } 2017 \\
\text { Tgl Diterima : } 27 \text { Feb. } 2018 \\
\text { Tersedia Online : } 5 \text { Mar. } 2018 \\
\text { Keywords: } \\
\text { Persistensi Laba, Kepemilikan } \\
\text { Manajerial, Ukuran } \\
\text { Perusahaan, Leverage, Fee } \\
\text { Audit, Konsentrasi Pasar. }\end{array}$ & $\begin{array}{l}\text { Penelitian ini bertujuan untuk mengetahui pengaruh } \\
\text { kepemilikan manajerial, ukuran perusahaan, leverage, fee } \\
\text { audit, dan konsentrasi pasar terhadap persistensi laba. } \\
\text { Data yang digunakan adalah data perusahaan property dan } \\
\text { real estate yang terdaftar di Bursa Efek Indonesia (BEI) } \\
\text { pada tahun 2013-2015. } \\
\text { Sampel dipilih dengan menggunakan motode purposive } \\
\text { sampling. Sampel yang sesuai kriteria diperoleh sebanyak } \\
32 \text { perusahaan selama periode pengamatan } 2013-2015 \text {, } \\
\text { jadi jumlah akhir data observasi yaitu } 96 \text { ( } 32 \times 3 \text { ). Kemudian } \\
\text { data dianalisis dengan menggunakan model analisis regresi } \\
\text { data panel dengan aplikasi EViews } 9 \text {. } \\
\text { Hasil penelitian menunjukan bahwa kepemilikan manajerial } \\
\text { tidak berpengaruh terhadap persistensi laba, karena } \\
\text { sedikitnya persentasi kepemilikan saham oleh manajerial. } \\
\text { Ukuran perusahaan berpengaruh negatif terhadap } \\
\text { persistensi laba, sedangkan leverage, fee audit dan } \\
\text { konsentrasi pasar berpengaruh positif terhadap persistensi } \\
\text { laba. Variabel kepemilikan manajerial, ukuran perusahaan, } \\
\text { leverage, fee audit dan konsentrasi pasar secara bersama- } \\
\text { sama berpengaruh terhadap persistensi laba. }\end{array}$ \\
\hline
\end{tabular}

\section{PENDAHULUAN}

Perkembangan standar akuntansi di Indonesia saat ini menuntut semua perusahaan terutama perusahaan go public untuk membuat laporan keuangan dengan menggunakan International Financial Reporting Standard (IFRS).

Penerapan standar IFRS di Indonesia bertujuan agar laporan keuangan yang dibuat manajemen, menjadi lebih berkualitas termasuk di dalamnya adalah kualitas laba (Sholikhati, 2015).
Laporan keuangan merupakan sebuah wujud pertanggungjawaban manajemen atas pengelolaan sumber daya perusahaan kepada pihak-pihak yang berkepentingan yang digunakan sebagai dasar untuk membuat beberapa keputusan, seperti penilaian kinerja manajemen, penentuan kompensasi manajemen, pemberian dividen kepada pemegang saham dan lain sebagainya (Fanani, 2010). Menurut Pernyataan Standar Akuntansi Keuangan (PSAK) paragraf 12 (IAI, 2015): "tujuan laporan keuangan adalah menyediakan informasi 
yang menyangkut posisi keuangan, kinerja serta perubahan posisi keuangan suatu perusahaan yang bermanfaat bagi sejumlah besar pemakai dalam pengambilan keputusan ekonomi".

Fokus utama laporan keuangan adalah informasi mengenai laba. Laba merupakan selisih pendapatan dan keuntungan setelah dikurangi beban dan kerugian (Subramanyam dan Wild, 2014:4). Menurut Jumiati dan Ratnadi (2014) "Laba yang disajikan dalam laporan keuangan merupakan suatu indikator dalam menilai kinerja pihak manajemen dalam mengalokasikan sumber daya". Informasi laba merupakan hal yang sangat penting bagi pihak-pihak yang terkait dalam perusahaan, baik itu pihak stakeholder maupun pihak manajemen perusahaan dalam menaksir laba perusahaan di masa yang akan datang. Begitu besarnya peranan dari informasi laba, maka kualitas laba menjadi hal yang sangat penting bagi para pengambil keputusan.

Schipper and Vincent (2003), menjelaskan bahwa:

Kualitas laba digunakan oleh investor dan kreditur sebagai dasar pengambilan keputusan ekonomi, khususnya yang berkaitan dengan pengambilan keputusan pembuatan kontrak (contracting decission), keputusan investasi (investment decision) dan digunakan sebagai salah satu indikator kualitas laba yang dihasilkan para pembuat standar (standard setters).

Keputusan melakukan kontrak yang didasarkan pada kualitas laba yang rendah menyebabkan transfer kesejahteraan yang tidak diinginkan. Salah satu contohnya adalah menaksir laba terlalu tinggi sebagai indikator kinerja manajemen, maka akan mengakibatkan kompensasi yang berlebih kepada manajer. Contoh kedua adalah laba yang ditaksir terlalu tinggi dapat menutupi kemampuan melunasi utang yang sesungguhnya dan memberikan informasi yang menyesatkan kepada kreditor untuk melanjutkan pemberian pinjaman atau menangguhkan penyitaan.

Menurut Djamaluddin dkk (2008): "laba yang berkualitas adalah laba yang dapat mencerminkan kelanjutan laba (sustainable earnings) di masa depan, yang ditentukan oleh komponen akrual dan kas dan dapat mencerminkan kinerja keuangan perusahaan yang sesungguhnya". Kualitas laba suatu perusahaan sering dikaitkan dengan persistensi laba, karena persistensi laba merupakan salah satu komponen nilai prediktif laba dalam menentukan kualitas laba (Suwandika dan Astika, 2013). Menurut Penman (2003): "persistensi laba merupakan laba yang mempunyai kemampuan sebagai indikator laba periode mendatang (future earning) yang dihasilkan oleh perusahaan secara berulang-ulang (repetitive) dalam jangka panjang (sustainable)".

Kualitas laba pada perusahaanperusahaan di Indonesia masih rendah, berbeda dengan beberapa negara maju seperti Amerika Serikat dan Australia yang termasuk negara dengan kualitas laba perusahaan yang tinggi (Boulton et al. 2011). Hal tersebut dapat dibuktikan dengan adanya fenomena beberapa perusahaan mendapatkan atau kehilangan sebagian besar labanya secara signifikan dalam kurun waktu yang singkat, fenomena ini bisa terjadi tak terkecuali pada sektor property dan real estate.

Bisnis property merupakan bisnis yang sangat menjanjikan dan hampir 
dapat dipastikan tidak akan pernah mati, karena kebutuhan akan papan merupakan kebutuhan pokok manusia dan setiap manusia berusaha untuk memenuhinya. Selain itu bisnis property merupakan salah satu pilihan bisnis yang memberikan jaminan kepastian nilai keuntungan kepada investor. Hal ini karena adanya peluang keuntungan dari naiknya harga lahan setelah property tersebut mulai dibangun (Kembar Pro, September 2009).

Di Indonesia sendiri perusahaan property dan real estate mempunyai kesempatan untuk berkembang mengingat penduduk Indonesia yang cukup banyak dan mempunyai kepemilikan rumah yang cukup rendah. Berdasarkan data statistik, terjadi kekurangan rumah berjumlah lebih kurang 15 juta unit. Permintaan akan hunian per tahun mencapai 700-800 ribu unit, sedangkan para pengembang hanya mampu menyediakan lebih kurang 400 ribu unit (Kembar Pro, September 2009). Tetapi pada kenyataannya, walaupun permintaan akan hunian cukup besar setiap tahunnya tidak menutup kemungkinan bahwa laba yang dihasilkan perusahaan property dan real estate bersifat tidak persisten atau tidak berkelanjutan. Hal ini dapat dibuktikan dengan adanya beberapa perusahaan property dan real estate yang mendapatkan dan kehilangan sebagian labanya diantaranya yaitu PT. Modernland Realty Tbk (MDLN), PT. Plaza Indonesia Realty Tbk (PLIN) dan PT. Sentul City Tbk (BKSL).

PT. Modernland Realty Tbk (MDLN) pada tahun 2013 yang tidak bisa menjamin laba yang persisten karena turun pada tahun 2014 sebesar 70,98 persen atau menjadi Rp 711,26 miliar dari laba bersih sebesar Rp 2,45 triliun di tahun 2013, padahal laba bersih PT.
Moderland Reality Tbk (MDLN) pada tahun 2013 meningkat sebesar 841\% yaitu menjadi Rp2,45 triliun dibanding tahun 2012 yang mencatat laba sebesar Rp260,5 miliar. (ekbis.sindonews.com). Sama halnya dengan laba bersih PT. Plaza Indonesia Realty Tbk (PLIN) yang tidak menunjukan persistensi labanya dengan membukukan laba bersih 2013 sebesar Rp 33,34 miliar atau anjlok 85,8 persen dibandingkan tahun sebelumnya tahun 2012 sebesar Rp 234,73 miliar. Kurangnya persistensi ini disebabkan penurunan laba dari penjualan unit-unit apartemen (ekbis.sindonews.com). Kemudian yang terakhir kasus perusahaan properti yang terjerat kasus suap yaitu PT. Sentul City Tbk (BKSL) dimana tidak menjamin laba yang persisten karana laba bersih sepanjang tahun 2014 turun. Perseroan mencetak laba bersih sebesar Rp 40,79 miliar pada tahun 2014, turun drastis 93,26 persen dari perolehan tahun 2013 senilai Rp 605,25 miliar (cnnindonesia.com).

Fenomena tersebut menyebabkan persistensi laba mulai dipertanyakan karena laba dengan fluktuasi menurun curam dalam waktu yang singkat menunjukan perusahaan tersebut tidak mampu untuk mempertahankan laba yang diperoleh saat ini maupun menjamin laba untuk masa depan. Bahkan karena laba dalam laporan keuangan sering digunakan oleh manajemen untuk menarik calon investor, sehingga laba tersebut sering direkayasa sedemikian rupa oleh manajemen untuk mempengaruhi keputusan investor (Fanani, 2010). Apabila angka laba diduga oleh publik sebagai hasil rekayasa manajemen, maka angka laba tersebut dinilai mempunyai kualitas laba yang rendah (Hanlon, 2005). Terkait dengan pentingnya persistensi laba bagi pengguna laporan keuangan, 
maka sangat penting pula untuk dilakukan analisis mengenai faktorfaktor yang dapat mempengaruhi persistensi suatu laba. Beberapa atribut yang diduga dapat mempengaruhi persisitensi laba antara lain, kepemilikan manajerial, ukuran perusahaan, leverage, fee audit, dan konsentrasi pasar.

Faktor kepemilikan manajerial, ukuran perusahaan dan leverage telah banyak diteliti oleh peneliti sebelumnya, namun hasil yang didapat dari beberapa penelitian tidak konsisten. Terdapat research gap yang signifikan antar hasil penelitian. Dengan research gap yang signifikan antar hasil penelitian yang satu dan yang lainnya serta pentingnya persistensi laba di Indonesia, mendorong penelitian ini dilakukan. Perbedaan penelitian ini dengan penelitian terdahulu yang telah banyak dilakukan pada perusahaan manufaktur dan perbankan yang terdaftar di BEI, penelitian ini mencoba menguji persistensi laba pada Perusahaan Property dan Real Estate yang terdaftar di BEl pada tahun 2013-2015, dan mencoba menambahkan variabel baru yang sebelumnya belum banyak diteliti dan diduga mempunyai pengaruh terhadap persistensi laba, yaitu fee audit yang disarankan oleh Juliardi (2013), dan konsentrasi pasar. Berdasarkan latar belakang diatas peneliti mengambil judul penelitian "Faktor-Faktor Yang Mempengaruhi Persistensi Laba (Studi Empiris pada Perusahaan Property dan Real Estate yang Terdaftar di Bursa Efek Indonesia Tahun 2013-2015)".

\section{TINJAUAN PUSTAKA}

\section{Agency Theory}

Teori agensi menekankan pentingnya pemilik perusahaan (pemegang saham) menyerahkan pengelolaan perusahaan kepada tenaga-tenaga professional yang disebut agen yang lebih mengerti dalam menjalankan bisnis sehari-hari. Tujuan dari dipisahkannya pengelolaan dari kepemilikan perusahaan yaitu agar pemilik perusahaan memperoleh keuntungan yang semaksimal mungkin dengan biaya yang seefisien mungkin dengan dikelolanya perusahaan oleh tenaga-tenaga professional.

Namun di sisi lain, pemisahan seperti ini memiliki segi negatifnya. Adanya keleluasaan pengelola manajemen perusahaan untuk memaksimalkan laba perusahaan bisa mengarah pada proses memaksimalkan kepentingannya pengelolaannya sendiri dengan beban dan biaya yang harus ditanggung oleh pemilik perusahaan. Lebih lanjut pemisahaan ini dapat pula menimbulkan kurangnya transparansi dalam penggunaan dana pada perusahaan serta keseimbangan yang tepat antara kepentingan-kepentingan yang ada, misalnya antara pemegang saham dengan pengelola manajemen perusahaan, dan antara pemegang saham pengendali dengan pemegang saham minoritas (Tandiontong, 2016:5).

Jensen dan Meckling (1976), menyatakan bahwa: "terdapat dua mekanisme untuk mengatasi konflik keagenan yaitu mekanisme pengikatan (bonding) dan mekanisme pengawasan (monitoring)". Penelitian ini memfokuskan pada mekanisme yang erat kaitannya dengan laporan keuangan 
yaitu mekanisme pengikatan yang direpresentasikan oleh kepemilikan. Hal ini dikarenakan pihak tersebut memiliki peran yang sangat besar dalam proses pelaporan keuangan untuk mempengaruhi laba yang dilaporkan dan memiliki pemahaman yang memadai atas laporan keuangan perusahaan. Dengan adanya kepemilikan manajemen diharapkan mampu mengurangi konflik keagenan dan asimetri informasi yang dihasilkan. Kepemilikan manajemen mendorong agen untuk tidak hanya bertindak sebagai agen tetapi juga sebagai prinsipal, sehingga manajer akan lebih meningkatkan kinerja perusahaan melalui perolehan laba.

\section{Signaling Theory}

Signaling theory memberikan pemahaman, bahwa informasi yang diberikan oleh pihak manajemen kepada pihak luar, akan menjadi sinyal bagi pasar. Isyarat atau sinyal menurut Brigham dan Houston (2010:185) adalah suatu tindakan manajemen perusahaan, yang memberikan petunjuk bagi investor tentang bagaimana manajemen memandang prospek perusahaan. Informasi mengenai jumlah aset yang mencerminkan ukuran perusahaan, tingkat leverage, besarnya fee audit, dan penjualan, yang terdapat dalam laporan hasil dari pertanggungjawaban manajemen atau pihak internal atas kinerjanya di perusahaan merupakan sinyal manajemen mengenai kemampuan perusahaan menghasilkan laba yang persisten. Perusahaan dapat meningkatkan kualitas laba yang persisten dengan mengurangi asimetri informasi yaitu dengan memberikan sinyal pada pihak luar, salah satunya berupa informasi keuangan positif dan bisa dipercaya yang akan mengurangi ketidakpastian mengenai prospek di masa depan.

\section{Kualitas Laba}

Kualitas laba adalah kemampuan laba dalam laporan keuangan untuk menjelaskan kondisi laba perusahaan yang sesungguhnya sekaligus digunakan dalam memprediksi laba masa depan, (Bellovary, 2005). Spiceland (2012) dalam Agrini (2015), mengartikan kualitas laba sebagai berikut:

Kualitas laba dalam akuntansi adalah penilaian sejauh mana laba sebuah perusahaan itu dapat diperoleh berulang-ulang, dapat dikendalikan, dan memenuhi syarat untuk mengajukan kredit/pinjaman pada bank, diantara faktor-faktor lainnya. Kualitas laba mengakui fakta bahwa dampak ekonomi transaksi yang terjadi akan beragam diantara perusahaan sebagai fungsi dari karakter dasar bisnis mereka, dan secara beragam dirumuskan sebagai tingkat laba yang menunjukkan apakah dampak ekonomi pokoknya lebih baik dalam memperkirakan arus kas ataukah konservatif, atau juga dapat diramalkan.

Sedangkan pengertian kualitas laba menurut Konsep Kualitatif Kerangka Kerja (International Accounting Standard Board, 2009), 'laba yang berkualitas adalah laba yang bermanfaat dalam pengambilan keputusan yang memiliki karakteristik relevan, dapat dipahami dan dapat diperbandingkan". Seperti yang telah dijelaskan laba merupakan salah satu bagian dari laporan keuangan yang mendapat banyak perhatian dan sering digunakan sebagai pertimbangan dalam pengambilan keputusan oleh para pengguna laporan keuangan, apabila laba yang disajikan tidak dapat diandalkan maka keputusan para pengguna yang didasarkan pada informasi dalam laporan keuangan juga tidak akan tepat. 


\section{Persistensi Laba}

Schipper dan Vincent (2003), Francis et al. (2004) menjelaskan bahwa: "persistensi merupakan suatu ukuran kualitas laba yang didasari pandangan bahwa laba yang lebih sustainable merupakan laba dengan kualitas yang lebih tinggi". Penman dan Zhang (2002) mendefinisikan: "persistensi laba sebagai revisi laba yang diharapkan di masa mendatang (expected future earnings) yang diimplikasikan oleh inovasi laba tahun berjalan." Besarnya revisi ini menunjukkan tingkat persistensi laba. Dalam penelitian Wijayanti (2006): "laba yang persisten adalah laba yang dapat mencerminkan kelanjutan laba (sustainable earnings) di masa depan yang ditentukan oleh komponen akrual dan aliran kasnya."

\section{Struktur Kepemilikan}

Dalam penelitian ini, struktur kepemilikan yang digunakan adalah struktur Kepemilikan manajemen. Kepemilikan manajerial adalah persentase kepemilikan saham oleh pihak manajemen yang secara aktif ikut dalam pengambilan keputusan perusahaan (Direktur dan Komisaris), dengan kata lain kepemilikan manajerial adalah situasi dimana manajer memiliki saham perusahaan, atau manajer tersebut sekaligus pemegang saham perusahaan (Tarigan 2007).

\section{Ukuran Perusahaan}

Ukuran perusahaan merupakan nilai yang menunjukkan besar kecilnya perusahaan (Taures, 2011). Besar kecilnya suatu perusahaan biasanya diukur berdasarkan total penjualan, ratarata tingkat penjualan dan total aset (Panjaitan dkk, 2004). Semakin besar instrumen tersebut, semakin besar pula ukuran perusahaan.

Menurut Romasari (2013):

Ukuran perusahaan dapat
menentukan baik tidaknya kinerja
perusahaan. Investor biasanya lebih
memiliki kepercayaan pada
perusahaan besar, karena perusahaan
besar dianggap mampu untuk terus
meningkatkan kinerja perusahaannya
dengan berupaya meningkatkan
kualitas labanya.

Menurut Machfoedz (1999:135): "pada dasarnya ukuran perusahaan hanya terbagi dalam tiga kategori yaitu: perusahaan besar (large firm), perusahaan menengah (medium firm), perusahaan kecil (small firm)." Sedangkan UU No. 20 Tahun 2008 mengklasifikasikan ukuran perusahaan ke dalam 4 kategori yaitu usaha mikro, usaha kecil, usaha menengah, dan usaha besar.

Dalam penelitian ini ukuran perusahaan diukur berdasarkan besaran total aset yang dimiliki oleh perusahaan. Total aset dipilih sebagai proksi ukuran perusahaan dengan mempertimbangkan bahwa nilai aset relatif lebih stabil dibandingkan dengan nilai market capitalized dan penjualan (Sudarmadji, 2007). Nuraini (2014) menyatakan bahwa "besaran total aset mewakili tersedianya sumber daya untuk kegiatan perusahaan di mana aset tersebut cenderung digunakan untuk memperoleh laba". Oleh karena itu, secara tidak langsung ukuran perusahaan dapat digunakan untuk menentukan kemampuan suatu perusahaan dalam mengendalikan serta menghasilkan laba.

\section{Leverage}

Leverage adalah bagian sumber pendanaan untuk operasional maupun 
investasi yang berasal dari luar perusahaan. Besarnya tingkat leverage mencerminkan kompleksitas dan risiko keuangan (Tumirin, 2003).

Pada saat tingkat leverage tinggi, dan digunakan seefisien mungkin maka tidak menutup kemungkinan pendanaan yang berasal dari utang tersebut menghasilkan laba yang dapat menutup pembayaran bunga dan pokok pinjaman. Namun jika manajemen tidak dapat menggunakan pendanaan yang berasal dari utang secara efisien kemungkinan laba yang dihasilkan kecil, maka kecil pula kemampuan perusahaan untuk pembayaran bunga dan pokok pinjamannya.

\section{Fee Audit}

Fee audit adalah besaran biaya yang diterima oleh auditor dengan mempertimbangkan berbagai hal seperti kompleksitas jasa yang diberikan, tingkat keahlian dan lain-lain. Menurut Sukrisno Agoes (2012:18) mendefinisikan fee audit sebagai berikut :

Besarnya biaya tergantung antara lain resiko penugasan, kompleksitas jasa yang diberikan, tingkat keahlian yang diperlukan untuk melaksanakan jasa tesebut, struktur biaya KAP yang bersangkutan dan pertimbangan professional lainnya.

Pada tahun 2016 Institut Akuntan Publik Indonesia (IAPI) menerbitkan Peraturan Pengurus No.2 tentang
Penentuan Imbalan Jasa Audit Laporan Keuangan yang digunakan sebagai panduan bagi profesi Akuntan Publik maupun Kantor Akuntan Publik dalam menetapkan fee audit. Dalam bagian Lampiran III dijelaskan bahwa panduan ini dikeluarkan sebagai panduan bagi seluruh anggota IAPI yang menjalankan praktek sebagai akuntan publik dalam menetapkan besaran imbalan yang wajar atas jasa profesional yang diberikannya dalam hal ini jasa audit.

\section{Konsentrasi Pasar}

Konsentrasi pasar merupakan jumlah dan ukuran distribusi penjual dan pembeli yang ada di pasar. Dennis dan Perloff (2000) mengartikan: "konsentrasi pasar sebagai kepemilikan terhadap sejumlah besar sumber daya ekonomi oleh sejumlah kecil pelaku ekonomi." Tingkat konsentrasi merupakan indikator dari struktur pasar. Apabila tingkat konsentrasi dalam suatu industri tinggi, maka tingkat persaingan antar perusahaan dalam industri tersebut rendah, dengan demikian struktur pasarnya mengarah ke bentuk monopoli. Sebaliknya, apabila tingkat konsentrasinya rendah maka struktur pasarnya mengarah ke bentuk oligopoly karena tingkat persaingan antar perusahaan dalam industrinya semakin tampak.

Tabel 2.1.

Ringkasan Penelitian Terdahulu

\begin{tabular}{|c|c|c|c|c|c|}
\hline NO. & $\begin{array}{c}\text { Peneliti } \\
\text { dan Tahun }\end{array}$ & Judul & Variabel & Hasil & $\begin{array}{l}\text { Perbedaan dengan } \\
\text { Penelitian Sekarang }\end{array}$ \\
\hline 1. & $\begin{array}{l}\text { Sari Agrini } \\
\text { (2015) }\end{array}$ & $\begin{array}{l}\text { Pengaruh Siklus } \\
\text { Operasi, } \\
\text { Volatilitas } \\
\text { Harga Saham, } \\
\text { Dan } \\
\text { Kepemilikan }\end{array}$ & $\begin{array}{l}\text { Independen: } \\
\text { Siklus Operasi, } \\
\text { Volatilitas Harga } \\
\text { Saham, Dan } \\
\text { Kepemilikan } \\
\text { Manajerial }\end{array}$ & $\begin{array}{l}\text { Siklus operasi tidak } \\
\text { berpengaruh signiifikan } \\
\text { terhadap persistensi } \\
\text { laba, volatilitas harga } \\
\text { saham berpengaruh } \\
\text { negatif signifikan }\end{array}$ & $\begin{array}{l}\text { Objek penelitian: } \\
\text { Perusahaan } \\
\text { Property dan Real } \\
\text { estate yang } \\
\text { terdaftar di BEI } \\
\text { tahun 2013-2015. }\end{array}$ \\
\hline
\end{tabular}




\begin{tabular}{|c|c|c|c|c|c|}
\hline NO. & $\begin{array}{c}\text { Peneliti } \\
\text { dan Tahun }\end{array}$ & Judul & Variabel & Hasil & $\begin{array}{c}\text { Perbedaan dengan } \\
\text { Penelitian Sekarang }\end{array}$ \\
\hline & & $\begin{array}{l}\text { Manajerial } \\
\text { Terhadap } \\
\text { Persistensi Laba } \\
\text { (Studi Kasus } \\
\text { Pada } \\
\text { Perusahaan } \\
\text { Consumer Goods } \\
\text { Yang Terdaftar } \\
\text { Di BEI Periode } \\
\text { Tahun 2011- } \\
\text { 2013) }\end{array}$ & $\begin{array}{l}\text { Dependen: } \\
\text { Persistensi laba }\end{array}$ & $\begin{array}{l}\text { terhadap persistensi } \\
\text { laba, sedangkan } \\
\text { kepemilikan manajerial } \\
\text { berpengaruh positif } \\
\text { signifikan terhadap } \\
\text { persistensi laba dan } \\
\text { siklus operasi, volatilitas } \\
\text { harga saham, } \\
\text { kepemilikan manajerial } \\
\text { secara simultan } \\
\text { berpengaruh terhadap } \\
\text { persistensi laba. }\end{array}$ & $\begin{array}{l}\text { Variabel } \\
\text { Independen : } \\
\text { Ukuran Perusahaan, } \\
\text { Leverage, Fee Audi, } \\
\text { dan Konsentrasi } \\
\text { Pasar. }\end{array}$ \\
\hline & $\begin{array}{l}\text { Jumiati } \\
\text { dan } \\
\text { Ratnadi } \\
(2014)\end{array}$ & $\begin{array}{l}\text { Pengaruh } \\
\text { Kepemilikan } \\
\text { Manajerial Dan } \\
\text { Book Tax } \\
\text { Differences } \\
\text { Pada Persistensi } \\
\text { Laba (Studi } \\
\text { Empiris pada } \\
\text { perusahaan } \\
\text { manufaktur } \\
\text { 2008-2011 yang } \\
\text { terdaftar di BEI) }\end{array}$ & $\begin{array}{l}\text { Independen: } \\
\text { Kepemilikan } \\
\text { Manajerial dan } \\
\text { Book Tax } \\
\text { Differences. } \\
\text { Dependen: } \\
\text { Persistensi laba }\end{array}$ & $\begin{array}{l}\text { Kepemilikan manajerial } \\
\text { berpengaruh posiitif } \\
\text { pada persistensi laba. } \\
\text { Large positive book tax } \\
\text { differences dan large } \\
\text { negative book tax } \\
\text { differences tidak } \\
\text { memilikipengaruh pada } \\
\text { persistensi laba, maka } \\
\text { perusahaan large } \\
\text { positive/negative book } \\
\text { tax differences tidak } \\
\text { lebih rendah persistensi } \\
\text { laba dibandingkan } \\
\text { perusahaan Small book } \\
\text { tax differences. }\end{array}$ & $\begin{array}{l}\text { Objek penelitian : } \\
\text { Perusahaan } \\
\text { Property dan Real } \\
\text { estate yang } \\
\text { terdaftar di BEl } \\
\text { tahun 2013-2015 } \\
\text { Variabel } \\
\text { Independen : Fee } \\
\text { Audit, Konsentrasi } \\
\text { Pasar, Ukuran } \\
\text { Perusahaan, dan } \\
\text { Leverage. }\end{array}$ \\
\hline 3. & $\begin{array}{l}\text { Septavita } \\
\text { (2016) }\end{array}$ & $\begin{array}{l}\text { Pengaruh Book } \\
\text { Tax Differences, } \\
\text { Arus Kas } \\
\text { Operasi, } \\
\text { Tingkat Utang, } \\
\text { Dan Ukuran } \\
\text { Perusahaan } \\
\text { Terhadap } \\
\text { Persistensi Laba } \\
\text { (Studi Empiris } \\
\text { Pada } \\
\text { Perusahaan } \\
\text { Manufaktur } \\
\text { Yang Terdaftar } \\
\text { Di Bei Tahun } \\
\text { 2011- 2013) }\end{array}$ & $\begin{array}{l}\text { Independen: } \\
\text { Book Tax } \\
\text { Differences, Arus } \\
\text { Kas Operasi, } \\
\text { Tingkat Utang, } \\
\text { Dan Ukuran } \\
\text { Perusahaan. } \\
\text { Dependen: } \\
\text { Persistensi laba }\end{array}$ & $\begin{array}{l}\text { Perbedaan permanen } \\
\text { tidak berpengaruh } \\
\text { signifikan terhadap } \\
\text { persistensi laba. } \\
\text { Sedangkan perbedaan } \\
\text { temporer, arus kas } \\
\text { operasi, tingkat utang, } \\
\text { ukuran perusahaan } \\
\text { berpengaruh signifikan } \\
\text { terhadap persistensi } \\
\text { laba. }\end{array}$ & $\begin{array}{l}\text { Objek penelitian : } \\
\text { Perusahaan } \\
\text { Property dan Real } \\
\text { estate yang } \\
\text { terdaftar di BEl } \\
\text { tahun 2013-2015 } \\
\text { Variabel } \\
\text { Independen: } \\
\text { Kepemilikan } \\
\text { Manajerial, Fee } \\
\text { Audit, Konsentrasi } \\
\text { Pasar. }\end{array}$ \\
\hline & $\begin{array}{c}\text { Malahayati } \\
(2015)\end{array}$ & $\begin{array}{l}\text { Pengaruh } \\
\text { Ukuran } \\
\text { Perusahaan Dan } \\
\text { Financial } \\
\text { Leverage } \\
\text { Terhadap } \\
\text { Persistensi } \\
\text { Laba, Dan } \\
\text { Dampaknya } \\
\text { Terhadap } \\
\text { Kualitas Laba } \\
\text { (Studi Pada } \\
\text { Perusahaan } \\
\text { Yang Terdaftar } \\
\text { Di Jakarta } \\
\text { Islamic Index) }\end{array}$ & $\begin{array}{l}\text { Independen: } \\
\text { Ukuran } \\
\text { Perusahaan Dan } \\
\text { Financial } \\
\text { Leverage. } \\
\text { Dependen: } \\
\text { Persistensi laba } \\
\text { dan Kualitas Laba }\end{array}$ & $\begin{array}{l}\text { Secara parsial ukuran } \\
\text { perusahaan dan financial } \\
\text { leverage berpengaruh } \\
\text { positif terhadap } \\
\text { persistensi laba. Ukuran } \\
\text { perusahaan, financial } \\
\text { leverage, dan persistensi } \\
\text { laba secara bersama- } \\
\text { sama berpengaruh } \\
\text { terhadap kualitas laba } \\
\text { pada perusahaan yang } \\
\text { terdaftar di Jakarta } \\
\text { Islamic Index. Secara } \\
\text { parsial ukuran } \\
\text { perusahaan berpengaruh } \\
\text { positif terhadap kualitas } \\
\text { laba, sedangkan } \\
\text { persistensi laba dan } \\
\text { financial leverage } \\
\text { berpengaruh negatif }\end{array}$ & $\begin{array}{l}\text { Objek penelitian: } \\
\text { Perusahaan } \\
\text { Property dan Real } \\
\text { estate yang } \\
\text { terdaftar di BEI } \\
\text { tahun 2013-2015 } \\
\text { Variabel } \\
\text { Independen: } \\
\text { Kepemilikan } \\
\text { Manajerial, Fee } \\
\text { Audit, Konsentrasi } \\
\text { Pasar. }\end{array}$ \\
\hline
\end{tabular}




\begin{tabular}{|c|c|c|c|c|c|}
\hline NO. & $\begin{array}{c}\text { Peneliti } \\
\text { dan Tahun }\end{array}$ & Judul & Variabel & Hasil & $\begin{array}{l}\text { Perbedaan dengan } \\
\text { Penelitian Sekarang }\end{array}$ \\
\hline & & & & $\begin{array}{l}\text { terhadap kualitas laba. } \\
\text { Persistensi laba } \\
\text { memediasi pengaruh } \\
\text { ukuran perusahaan dan } \\
\text { financial leverage } \\
\text { terhadap kualitas laba } \\
\text { pada perusahaan yang } \\
\text { terdaftar di Jll. }\end{array}$ & \\
\hline 6. & $\begin{array}{c}\text { Fanani dkk } \\
(2008)\end{array}$ & $\begin{array}{l}\text { Faktor-Faktor } \\
\text { Penentu } \\
\text { Kualitas } \\
\text { Pelaporan } \\
\text { Keuangan Dan } \\
\text { Kepercayaan } \\
\text { Investor }\end{array}$ & $\begin{array}{l}\text { Independen: } \\
\text { Siklus Operasi, } \\
\text { Volatilitas } \\
\text { Penjualan, Ukuran } \\
\text { Perusahaan, } \\
\text { Umur } \\
\text { Perusahaan, } \\
\text { Proporsi } \\
\text { Kerugian, } \\
\text { Likuiditas, } \\
\text { Leverage, Resiko } \\
\text { Lingkungan, } \\
\text { Kepemilikan } \\
\text { Manajerial, } \\
\text { Kepemilikan } \\
\text { Institusional, } \\
\text { Konsentrasi } \\
\text { Pasar, Kualitas } \\
\text { Auditor, dan } \\
\text { Pertumbuhan } \\
\text { Investasi } \\
\text { Dependen: } \\
\text { pelaporan } \\
\text { keuangan dibagi } \\
\text { menjadi dua: } \\
\text { kualitas keuangan } \\
\text { faktorial } \\
\text { akuntansi } \\
\text { (Persistensi, } \\
\text { Prediktibilitas, } \\
\text { Perataan) dan } \\
\text { factorial pasar } \\
\text { (Relevansi Nilai, } \\
\text { Ketepatwaktuan, } \\
\text { Konservatisme) }\end{array}$ & $\begin{array}{l}\text { siklus operasi, volatilitas } \\
\text { penjualan, ukuran } \\
\text { perusahaan, } \\
\text { Berpengaruh negatif dan } \\
\text { signfikan untuk semua } \\
\text { variabel kualitas } \\
\text { pelaporan keuangan. } \\
\text { Umur perusahaan, } \\
\text { proporsi kerugian, resiko } \\
\text { lingkungan Berpengaruh } \\
\text { negatif dan signfikan } \\
\text { untuk } \\
\text { kualitas pelaporan } \\
\text { keuangan berbasis pasar, } \\
\text { dan kualitas pelaporan } \\
\text { keuangan dan tidak } \\
\text { signifikan untuk kualitas } \\
\text { pelaporan keuangan } \\
\text { berbasis akuntansi. } \\
\text { Likuiditas, kepemilikan } \\
\text { manajerial, } \\
\text { pertumbuhan investasi } \\
\text { Tidak berpengaruh } \\
\text { signfikan untuk semua } \\
\text { variabel kualitas } \\
\text { pelaporan keuangan. } \\
\text { Leverage, konsentrasi } \\
\text { pasar dan kualitas } \\
\text { auditor berpengaruh } \\
\text { positif dan signfikan } \\
\text { untuk kualitas pelaporan } \\
\text { keuangan berbasis } \\
\text { akuntansi, kualitas } \\
\text { pelaporan keuangan dan } \\
\text { tidak signifikan untuk } \\
\text { kualitas pelaporan } \\
\text { keuangan berbasis pasar. } \\
\text { Kepemilikan } \\
\text { institusional, } \\
\text { Berpengaruh positif dan } \\
\text { signfikan untuk kualitas } \\
\text { pelaporan keuangan } \\
\text { berbasis akuntansi, } \\
\text { kualitas pelaporan } \\
\text { keuangan berbasis pasar, } \\
\text { dan kualitas pelaporan } \\
\text { keuangan. }\end{array}$ & $\begin{array}{l}\text { Objek penelitian: } \\
\text { Perusahaan } \\
\text { Property dan Real } \\
\text { estate yang } \\
\text { terdaftar di BEI } \\
\text { tahun 2013-2015. } \\
\text { Variabel } \\
\text { Independen: Fee } \\
\text { Audit. }\end{array}$ \\
\hline
\end{tabular}




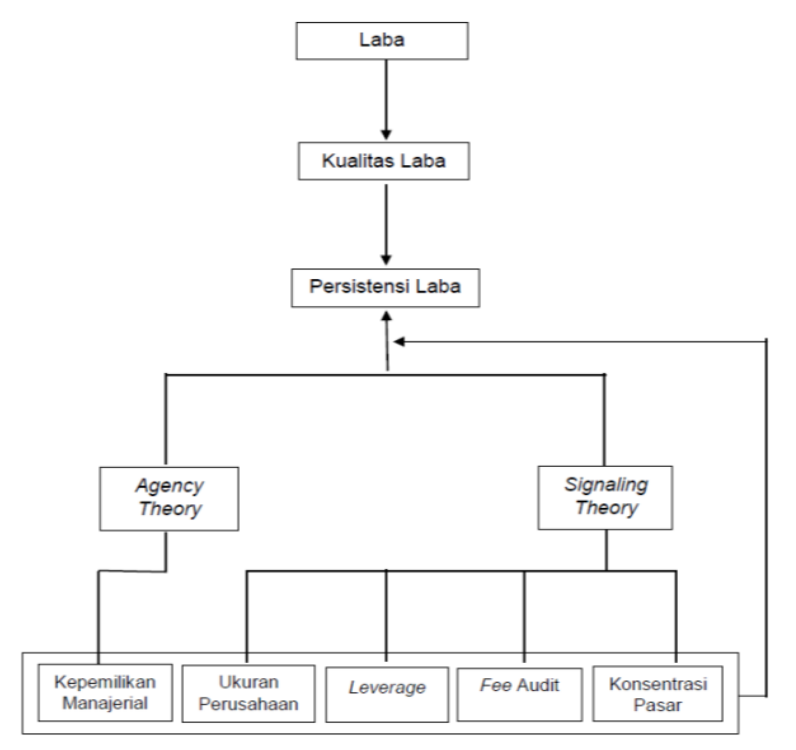

Gambar 2.1.

Kerangka Pemikiran

Sumber: (Penulis, 2017)

\section{PENGEMBANGAN HIPOTESIS}

\section{Pengaruh Kepemilikan Manajerial terhadap Persistensi Laba}

Persistensi laba merupakan harapan yang diinginkan oleh para pemegang saham. Namun adanya kepentingan yang berbeda antara pemegang saham dan manajemen perusahaan sering terjadi kasus manipulasi laba. Perbedaan kepentingan antara pemegang saham dan pihak manajemen perusahaan ini merupakan kenyataan empiris yang tidak dapat dihindari dari sebuah hubungan keagenan. Menurut Jensen dan Meckling (1976), menyatakan bahwa: "salah satu cara untuk mengurangi agency cost adalah dengan meningkatkan kepemilikan saham oleh manajemen". Struktur kepemilikan akan memiliki motivasi yang berbeda dalam memonitor perusahaan serta manajemen dan dewan direksinya. Struktur kepemilikan dipercaya memiliki kemampuan untuk mempengaruhi jalannya perusahaan yang nantinya dapat mempengaruhi kinerja perusahaan.

Menurut Jumiati dan Ratnadi (2014):

Kepemilikan manajerial dapat digunakan untuk menentukan kualitas laba mendatang yang tercermin dari persistensi labanya, semakin pihak manajemen memiliki saham perusahaan berarti semakin besar rasa tanggung jawab manajer untuk mempertanggungjawabkan laporan keuangan.

Hal ini dikarenakan tindakan manajer sesuai dengan keinginan pemegang saham dan memberikan kesempatan kepada manajer terlibat dalam kepemilikan saham sehingga manajer bertindak lebih berhati-hati karena ikut menanggung konsekuensi atas keputusan yang diambilnya (Demsetz dan Lehn, 1985). Pendapat tersebut didukung oleh hasil penelitian yang dilakukan oleh Agrini (2015), Jumiati dan Ratnadi (2014) bahwa kepemilikan manajerial berpengaruh positif terhadap persistensi laba, artinya semakin besar kepemilikan saham yang dimiliki manajerial semakin tinggi tingkat persistensi laba suatu perusahaan. Dari hasil uraian di atas, maka dapat ditarik hipotesis sebagai berikut:

H1: Kepemilikan manajerial berpengaruh positif terhadap persistensi laba

\section{Pengaruh Ukuran Perusahaan terhadap Persistensi Laba}

Ukuran perusahaan merupakan nilai yang menunjukkan besar kecilnya perusahaan (Taures, 2011). Besar kecilnya suatu perusahaan biasanya diukur berdasarkan total penjualan, ratarata tingkat penjualan dan total aset 
(Panjaitan dkk, 2004). Menurut Romasari (2013):

Ukuran perusahaan dapat menentukan baik tidaknya kinerja perusahaan. Investor biasanya lebih memiliki kepercayaan pada perusahaan besar, karena perusahaan besar dianggap mampu untuk terus meningkatkan kinerja perusahaannya dengan berupaya meningkatkan kualitas labanya.

Perusahaan besar yang telah mencapai tahap kedewasaan mencerminkan bahwa perusahaan relatif lebih stabil dan lebih mampu menghasilkan laba dibandingkan perusahaan kecil. Bagi perusahaan yang stabil biasanya tingkat kepastian untuk memperoleh laba sangat tinggi. Sebaliknya, bagi perusahaan kecil besar kemungkinan laba yang diperoleh juga belum stabil karena tingkat kepastian laba lebih rendah. Hal ini sesuai dengan pendapat Dechow dan Dichev (2002) bahwa "perusahaan yang besar akan memiliki kestabilan dan operasi yang dapat diprediksi lebih baik, sehingga kesalahan estimasi yang ditimbulkan akan menjadi lebih kecil".

Selain itu, perusahaan besar akan memiliki sumber daya yang besar untuk digunakan dalam kegiatan usaha (Yustiana, 2011). Meskipun demikian, perusahaan besar akan banyak menghadapi sensitivitas politik yang tinggi dan menghadapi biaya politis yang lebih tinggi dari pada perusahaan kecil (Gu et al., 2002). Biaya politis diantaranya ialah intervensi pemerintah, pengenaan pajak, dan berbagai macam tuntutan lain. Untuk mengurangi biaya politis, manajer akan cenderung untuk menggunakan pilihan akuntansi yang dapat mengurangi laba (Watts dan Zimmerman, 1986). Hasil penelitian Malahayati (2015), Nuraini (2014) menyatakan bahwa ukuran perusahaan berpengaruh positif terhadap persistensi laba, sedangkan penelitian yang dilakukan Septavita (2015), hanya menyebutkan bahwa ukuran perusahaan berpengaruh terhadap persistensi laba. Dari hasil uraian di atas, maka dapat ditarik hipotesis sebagai berikut:

H2: Ukuran Perusahaan berpengaruh positif terhadap persistensi laba

\section{Pengaruh Leverage terhadap Persistensi Laba}

Kemampuan perusahaan dalam memperoleh laba tidak dapat terlepas dari sumber modal perusahaan guna membiayai kegiatan perusahaan agar dapat terus mengembangkan usahanya dan menghasilkan laba yang maksimal. Salah satu sumber modal perusahaan adalah utang. Utang merupakan salah satu cara untuk mendapat tambahan pendanaan dari pihak kesternal, dengan konsekuensi perusahaan akan menjalin ikatan kontrak dengan kreditur. Tingkat utang yang tinggi bisa member insentif yang lebih kuat bagi manajer untuk mengelola laba pada prosedur yang bisa diterima (Rahmadhani, 2016). Penggunaan utang bisa dibenarkan sejauh diharapkan bisa memberikan tambahan laba operasi yang lebih besar dari bunga yang dibayarkan, untuk mencapai laba operasi yang lebih besar maka penggunaan utang diarahkan kepada investasi yang menghasilkan, misalnya: persediaan untuk dijual kembali.

Tingkat utang berpengaruh terhadap persistensi laba, setiap perusahaan selalu ingin mengembangkan perusahaannya dengan cara 
menambah utang sebagai tambahan modal. Maka dari itu, ketika perusahaan mempunya tingkat leverage yang tinggi perusahaan akan meningkatkan persistensi laba dengan tujuan untuk mempertahankan kinerja perusahaan yang baik dimata investor. Dengan kinerja yang baik diharapkan kreditor tetap memiliki kepercayaan terhadap perusahaan, tetap mengucurkan dana, dan perusahaan akan memperoleh kemudahan dalam proses pembayaran. Begitu juga kepada investor, perusahan dapat memberikan gambaran kinerja perusahaan, bahwa perusahaan mampu mempertahankan laba di masa mendatang meskipun biaya yang dikeluarkan perusahaa bertambah yaitu biaya bunga atas pinjaman (Rahmadhani, 2016), hal ini sesuai dengan signaling theory, bahwa manajemen atau pihak internal akan memberikan sinyal pada pihak luar, salah satunya berupa informasi keuangan positif dan bisa dipercaya yang akan mengurangi ketidakpastian mengenai prospek di masa depan

Hal ini didukung oleh penelitian yang dilakukan oleh Fanani (2010), dan Rahmadhani (2016), yang menyatakan bahwat tingkat utang perusahaan yang besar akan menyebabkan perusahaan meningkatkan persistensi laba dengan tujuan untuk mempertahankan kinerja perusahaan yang baik di mata auditor dan investor. Dengan demikian, maka ditarik hipotesis sebagai berikut:

H3: Leverage berpengaruh positif terhadap persistensi laba.

\section{Pengaruh Fee Audit terhadap Persistensi Laba}

Fee audit adalah besaran biaya yang diterima oleh auditor dengan mempertimbangkan berbagai hal seperti kompleksitas jasa yang diberikan, tingkat keahlian dan lain-lain. Menurut Sukrisno Agoes (2012:18) mendefinisikan Fee Audit sebagai berikut: "Besarnya biaya tergantung antara lain resiko penugasan, kompleksitas jasa yang diberikan, tingkat keahlian yang diperlukan untuk melaksanakan jasa tesebut, struktur biaya KAP yang bersangkutan dan pertimbangan profesional lainya".

Supriyono dalam Novitasari (2004:26):

Masyarakat memandang bahwa pemberian fee audit yang jumlahnya besar dapat menyebabkan berkurangnya independensi auditor, hal ini dikarenakan pertama, kantor akuntan yang mendapat fee besar merasa tergantung pada klien sehingga cenderung segan untuk menentang kehendak klien. Kedua, jika tidak memberikan opini sesuai keinginan klien, kantor akuntan khawatir akan kehilangan kliennya mengingat pendapatan yang akan diterimanya relatif besar. Ketiga, KAP cenderung memberikan counterpart fee yang besar kepada salah satu atau beberapa pejabat kunci klien yang diaudit, meskipun tindakan ini dilarang oleh Kode Etik.

Akan tetapi, fee audit yang besar mungkin juga dapat mendorong KAP lebih independen karena dengan fee yang besar dapat tersedia dana untuk penelitian dan penerapan prosedur audit yang lebih luas dan seksama, dan kemungkinan fee audit yang diterima dari klien merupakan sebagian besar dari total pendapatan kantor akuntan atau hanya merupakan sebagian kecil dari total pendapatan kantor akuntan tersebut. Gammal (2012) membuktikan bahwa perusahaan multinasional dan bank-bank di Lebanon lebih memilih untuk membayar biaya audit yang 
bernominal besar dengan alasan yaitu mereka lebih mencari auditor dalam kantor akuntan publik yang dapat menghasilkan laporan audit yang berkualitas dan dapat meningkatkan kredibilitas laporan keuangan tahunan yang dapat bersaing diseluruh dunia. Dengan adanya auditor eksternal yang independen diharapkan dapat mendorong manajemen untuk meningkatkan kinerja salah satunya dengan melaporkan laba yang berkualitas atau laba yang persisten dan mengurangi praktik manjemen laba. Dari hasil uraian di atas, maka dapat ditarik hipotesis sebagai berikut:

H4: Fee audit berpengaruh positif terhadap persistensi laba

\section{Pengaruh Konsentrasi Pasar terhadap Persistensi Laba}

Konsentrasi dapat diartikan sebagai persentase pangsa pasar yang dikuasai oleh perusahaan relatif terhadap pangsa pasar total. Pada prinsipnya konsentrasi tidak disebabkan karena faktor kebetulan tetapi karena adanya kekuatan permanen yang terletak di belakang konsentrasi yang biasanya tidak banyak berubah dari waktu ke waktu. Konsentrasi juga menunjukkan tingkat produksi dari pasar atau industri yang hanya terfokus pada satu atau beberapa perusahaan terbesar. Semakin besar pangsa pasar yang dikuasai oleh perusahaan-perusahaan tersebut relatif terhadap total pangsa pasar, maka dapat dikatakan bahwa industri tersebut mempunyai tingkat konsentrasi yang tinggi (Fajri, 2013).

Pangsa pasar bersinggungan
langsung dengan laba hal tersebut
dikarenakan adanya faktor penjualan dalam pangsa pasar. Semakin besar penjualan perusahaan, dan perusahaan dapat mempertahankan penjualan maka akan mempengaruhi laba perusahaan. Jika segmen pasar perusahaan besar perusahaan mempunyai posisi kuat dalam kompetisi, perusahaan akan memberikan sinyal tentang masa depan perusahaan yang lebih baik melalui persistensi labanya (Fanani dkk, 2008). Menurut Nuswantara (2004), Konsentrasi pasar berhubungan positif dengan kualitas pelaporan keuangan karena perusahaan dengan konsentrasi industri tinggi cenderung untuk memilih kebijakan akuntansi yang menurun di masa yang akan datang. Hasi penelitian Fanani dkk (2008), konsentrasi pasar berpengaruh positif terhadap kualitas pelaporan keuangan berbasis akuntansi yang diproksikan dengan persistensi, prediktibilitas dan perataan. Dari hasil uraian di atas, maka dapat ditarik hipotesis sebagai berikut:

\section{H5: Konsentrasi pasar berpengaruh positif terhadap persistensi laba}

\section{Pengaruh Kepemilikan Manajerial, Ukuran Perusahaan, Fee Audit, Leverage, dan Konsentrasi Pasar Terhadap Persistensi Laba}

Agency Theory mengemukakan untuk mengatasi agency problems dalam pengelolaan perusahaan, diperlukan suatu mekanisme pengendalian yang dapat menyelaraskan kepentingan manajemen dan pemegang saham. Kepemilikan saham oleh manajemen diharapkan dapat menyelaraskan perbedaan kepentingan tersebut. Hal ini dikarenakan tindakan manajer sesuai dengan keinginan pemegang saham dan memberikan kesempatan kepada manajer terlibat dalam kepemilikan 
saham sehingga manajer bertindak lebih berhati-hati dalam pengambilan keputusan, karena ikut menanggung konsekuensi atas keputusan yang diambilnya (Demsetz dan Lehn, 1985). Selain itu manajemen juga akan lebih bertanggung jawab atas laporan keuangan yang dibuatnya dengan melaporkan laba yang sesungguhnya atau mengurangi praktik manajemen laba sehingga laba yang dilaporkan berkualitas atau persisten.

Sedangkan Signaling Theory menjelaskan bahwa informasi yang dikemukakan pihak manajemen kepada pihak luar merupakan isyarat atau sinyal bagi pasar. Dimana isyarat atau sinyal merupakan tindakan manajemen perusahaan, yang memberikan petunjuk bagi investor tentang bagaimana manajemen memandang prospek perusahaan. Informasi mengenai jumlah aset yang mencerminkan ukuran perusahaan, tingkat leverage, besarnya fee audit, dan penjualan, yang terdapat dalam laporan hasil dari pertanggungjawaban manajemen atau pihak internal atas kinerjanya di perusahaan merupakan sinyal manajemen mengenai kemampuan perusahaan menghasilkan laba yang persisten.

Berdasarkan dua teori yang telah dijelaskan, perlu dilakukannya penelitian secara simultan dari pengaruh kepemilikan manajerial, ukuran perusahaan, leverage, fee audit dan konsentrasi pasar terhadap persistensi laba. Sehingga dibuat hipotesis keenam dalam penelitian ini, yaitu sebagai berikut:

H6: Kepemilikan manajerial, ukuran perusahaan, leverage, fee audit dan konsentrasi pasar secara simultan berpengaruh terhadap persistensi laba

\section{METODE PENELITIAN}

Dalam penelitian ini sumber data yang digunakan adalah sumber sekunder, dimana data diperoleh dari laporan keuangan tahunan perusahaan property dan real estate yang terdaftar di BEI pada tahun 2013-2015. Metode pengumpulan data yang digunakan dalam penelitian ini adalah studi kepustakaan, yaitu data diperoleh dari beberapa literatur yang berkaitan dengan masalah yang sedang diteliti, penelusuran data ini dilakukan dengan cara:

1. Penelusuran secara manual untuk data dalam format kertas hasil cetakan. Data yang disajikan dalam format kertas hasil cetakan yang antara lain berupa jurnal, buku, skripsi dan thesis.

2. Penelusuran dengan menggunakan komputer untuk data dalam format elektronik. Data yang disajikan dalam format elektronik ini antara lain berupa laporan keuangan, laporanlaporan BEI, dan situs internet lainnya.

Alat statistika yang digunakan dalam penelitian ini adalah Microsoft Excel dan program EViews 9, kelebihan dari program EViews 9 sendiri adalah kemudahan penggunaan dan menyediakan fasilitas metode estimasi regresi yang lebih lengkap dibandingkan software lain.

Teknik pemilihan sampel yang digunakan adalah Sampling Purposive. Sampling Purposive adalah teknik penentuan sampel dengan pertimbangan tertentu (Sugiyono, 2016:85). Adapun 
pertimbangan dalam penentuan kriteria sampel pada penelitian ini adalah:

1. Sampel adalah perusahaan property dan real estate yang terdaftar di BEI.

2. Perusahaan property dan real estate yang Initial Public Offering diatas tahun 2009.

3. Perusahaan sampel memiliki laporan keuangan tahunan yang berakhir pada tanggal 31 Desember dan disajikan dalam mata uang berbentuk rupiah.

4. Perusahaan sampel telah menerbitkan laporan keuangan tahunan yang telah diaudit untuk periode 2009-2015.

5. Komponen laporan keuangan yang diperlukan dalam penelitian ini telah tersedia.

Tabel 3.1.

Variabel Penelitian dan Pengukurannya

\begin{tabular}{|c|c|c|c|c|c|}
\hline No & $\begin{array}{l}\text { Nama } \\
\text { Variabel }\end{array}$ & Definisi & Pengukuran & Skala & Sumber \\
\hline 1. & $\begin{array}{l}\text { Persistensi } \\
\text { Laba }\end{array}$ & $\begin{array}{l}\text { Revisi laba yang diharapkan di masa } \\
\text { mendatang (expected future earnings) } \\
\text { yang diimplikasikan oleh inovasi laba } \\
\text { tahun berjalan. }\end{array}$ & $E_{i t}=\beta 0+\beta 1 E_{i t}+\varepsilon_{i t}$ & Rasio & $\begin{array}{l}\text { Kormendi \& } \\
\text { Lipe (1987), } \\
\text { Easton \& } \\
\text { Zmijweski } \\
(1989)\end{array}$ \\
\hline 2. & $\begin{array}{l}\text { Kepemilikan } \\
\text { Manajerial }\end{array}$ & $\begin{array}{l}\text { Kepemilikan perusahaan mencerminkan } \\
\text { hak kepemilikan manajerial pada suatu } \\
\text { perusahaan }\end{array}$ & $\frac{\text { Saham Manajemen }}{\text { Saham Beredar }} \times 100 \%$ & Rasio & $\begin{array}{l}\text { Tarigan } \\
(2007)\end{array}$ \\
\hline 3. & $\begin{array}{l}\text { Ukuran } \\
\text { Perusahaan }\end{array}$ & Skala besarnya perusahaan & Logaritma Total Aset & Rasio & $\begin{array}{l}\text { Dechow \& } \\
\text { Dechiv } \\
(2002)\end{array}$ \\
\hline 4. & Leverage & $\begin{array}{l}\text { Adanya bagian sumber pendanaan } \\
\text { untuk operasional maupun investasi } \\
\text { yang berasal dari luar perusahaan }\end{array}$ & $\frac{\text { Total Utang }_{\mathrm{jt}}}{\text { Total Aset }_{\mathrm{jt}}}$ & Rasio & $\begin{array}{l}\text { DeAngelo et } \\
\text { al. (1994) }\end{array}$ \\
\hline 5. & Fee Audit & Besaran biaya yang diterima oleh auditor & Jumlah Professional Fees & Rasio & $\begin{array}{l}\text { Hartadi } \\
(2009)\end{array}$ \\
\hline 6. & $\begin{array}{l}\text { Konsentrasi } \\
\text { Pasar }\end{array}$ & $\begin{array}{l}\text { Posisi relatif perusahaan-perusahaan } \\
\text { dalam penyediaan barang-barang }\end{array}$ & $\frac{\text { Penjualan }}{\text { Total Penjualan Industri }} \times 100 \%$ & Rasio & $\begin{array}{l}\text { Nuswantara } \\
(2004)\end{array}$ \\
\hline
\end{tabular}

\section{HASIL DAN PEMBAHASAN}

\section{Analisis Hasil Pengumpulan Data}

Data yang digunakan dalam penelitian ini merupakan data perusahaan property dan real estate yang terdaftar di Bursa Efek Indonesia (BEI), periode penelitian selama tiga tahun yaitu tahun 2013-2015. Teknik pengumpulan data yang digunakan adalah teknik purposive sampling, yaitu berdasarkan kriteria yang telah ditentukan untuk menentukan sampel, dari 47 perusahaan property dan real estate yang terdaftar di BEI hanya 32 perusahaan yang memenuhi kriteria tersebut. Proses pemilihan sampel dapat dilihat pada tabel 4.1.

\section{Tabel 4.1.}

Proses Seleksi Sampel Berdasarkan Kriteria

Tabel 4.1.

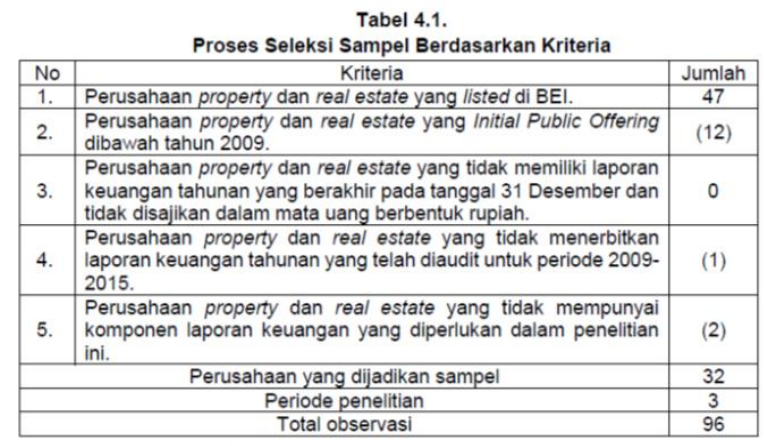

Sumber: (Penulis, 2017) 
Berdasarkan Tabel 4.1. dari 32 perusahaan property dan real estate dengan periode penelitian selama 3 tahun, membentuk data panel yang dimiliki sebanyak 96 observasi ( $3 \times 32)$.

Persistensi laba dihitung dengan cara meregresikan laba setelah pajak selama lima tahun, sehingga untuk menghitung persistensi laba tahun 2013 dibutuhkan data laba setelah pajak dari tahun 2009-2013 dan seterusnya (dilampirkan). Berikut ini merupakan grafik tren rata-rata persistensi laba hasil dari regresi:

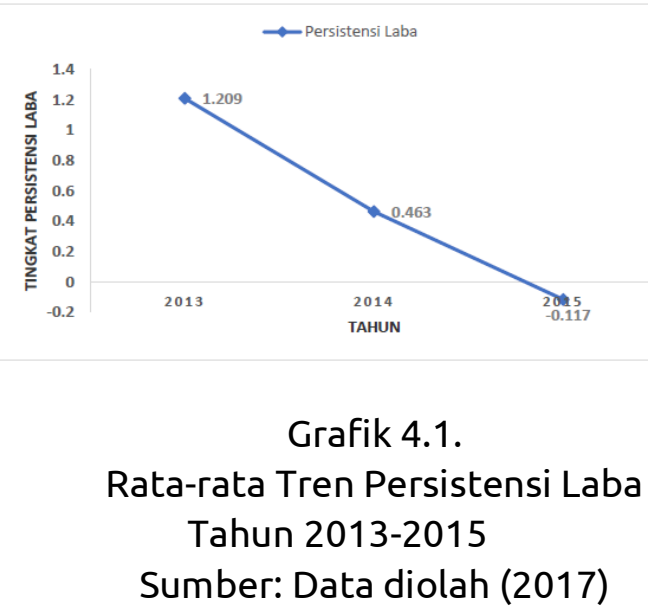

Pada garfik 4.1. menunjukkan dengan jelas tren rata-rata persistensi laba dari tahun 2013-2015 mengalami penurunan secara tajam, hal ini menunjukan bahwa tingkat kualitas laba yang dimiliki oleh perusahaan property dan real estate di Indonesia masih rendah sesuai dengan yang dikemukakan Boulton et al. 2011 bahwa kualitas laba pada perusahaan-perusahaan di Indonesia masih rendah, berbeda dengan beberapa negara maju seperti Amerika Serikat dan Australia yang termasuk negara dengan kualitas laba perusahaan yang tinggi.

Tren penurunan persistensi laba ini sesuai dengan yang dikemukakan Indonesia Investment (10 Juli 2015) bahwa pada tahun 2012 dan pertengahan 2013 perusahaan property dan real estate mengalami pertumbuhan yang signifikan. Hal itu memberikan keuntungan bagi developer atau pengembang pada sektor tersebut, tercatat 26 perusahaan dari 45 perusahaan yang terdaftar di Bursa Efek Indonesia pada tahun 2012 memiliki laba bersih lebih dari $50 \%$. Pertumbuhan itu terjadi karena ekspansi perekonomian yang subur, meskipun Pertumbuhan Domestik Bruto (PDB) pada tahun 2012 hanya 6,2\% dibawah PDB tahun 2011 sebesar $6,5 \%$ yang kala itu sedang mengalami Krisis Finansial Asia tahun 2011. Kemudian menurut Investasi Kontan (05 Agustus 2015) pada tahun 2015 pertumbuhan ekonomi Indonesia melambat karena Rupiah mengalami penurunan nilai tukar tehadap mata uang Dollar Amerika sehingga menyebabkan menurunnya daya beli masyarakat. Seperti sektor lain, kinerja industri properti juga melambat di semester pertama tahun 2015. Rata-rata laba bersih tujuh emiten properti yang telah merilis laporan keuangan semester I 2015 menyusut 16,3\%. Laba bersih sebagian emiten tertekan akibat membengkaknya beban terutama beban selisih kurs, akibat melemahnya nilai tukar rupiah terhadap dollar Amerika Serikat

Tingkat persistensi laba yang menurun juga mengindikasi adanya komponen transitori pada laba yang merupakan komponen yang hanya berpengaruh pada periode tertentu, terjadinya tidak persisten atau tidak terus menerus, dan mengakibatkan angka laba (rugi) yang dilaporkan dalam laporan laba rugi berfluktuasi. Adanya komponen transitori pada laba menyebabkan laba bersifat kurang 
permanen atau laba mempunyai persisten yang rendah.

Pada tahun 2013 rata-rata tingkat persistensi laba perusahaan property dan real estate sebesar 1.209, hal ini menunjukkan bahwa pada tahun 2013 sebagian besar perusahaan property dan real estate mempunyai laba yang high persisten karena rata-rata koefisien regresi melebihi 1 sehingga dapat dikatakan high persisten. Rata-rata tingkat persistensi laba perusahaan property dan real estate pada tahun 2014 sebesar 0.463 , artinya bahwa sebagian besar perusahaan property dan real estate mempunyai laba yang persisten, sedangkan pada tahun 2015 rata-rata koefisien regresi perusahaan property dan real estate sebesar - 0.177 , artinya bahwa pada tahun 2015 sebagian besar perusahaan property dan real estate mempunyai laba yang tidak persisten atau berfluktuatif.

\section{Hasil Penelitian}

Dalam penelitian ini terdapat beberapa tahapan dalam menjelaskan hasil penelitian. Pertama, untuk menggambarkan setiap variabel akan dijelaskan dalam analisis deskriptif. Kedua, melakukan pembuatan model menggunakan analisis regresi data panel, setelah diperoleh model maka ditentukan model terbaik berdasarkan tiga uji pemilihan model. Kemudian dilakukan uji asumsi klasik untuk menguji kelayakan model regresi yang diteliti. Uji asumsi klasik terdiri dari tiga jenis uji, yakni uji normalitas, uji heterokedastisitas, dan uji autokorelasi. Setelah memenuhi uji asumsi klasik maka dilakukan penarikan kesimpulan dengan menguji hipotesis yang diajukan dalam penelitian ini.

\section{Analisis Statistik Deskriptif}

Statistik deskriptif digunakan untuk menggambarkan suatu data penelitian berdasarkan output EViews statistik deskriptif meliputi mean, median, minimum, maximum, standar deviasi, skewness, kurtosis, Jarque Bera, probabilitas, dan observations. Statistik deskriptif ditunjukkan oleh tabel 4.3. di bawah ini:

Tabel 4.3.

Statistik Deskriptif

\begin{tabular}{|c|c|c|c|c|c|c|}
\hline & $\begin{array}{l}\text { PERSISTEN } \\
\text { SI LABA }\end{array}$ & $\begin{array}{l}\text { KEPEMILIKAN } \\
\text { MANAJERIAL }\end{array}$ & $\begin{array}{c}\text { UKURAN } \\
\text { PERUSAH } \\
\text { AAN }\end{array}$ & LEVERAGE & FEE AUDIT & $\begin{array}{c}\text { PANGSA } \\
\text { PASAR }\end{array}$ \\
\hline Mean & 0.518407 & 0.036598 & 12.51606 & 0.401656 & $1.57 \mathrm{E}+10$ & 0.031248 \\
\hline Median & 0.269246 & 0.000000 & 12.66350 & 0.405000 & $6.49 E+09$ & 0.017950 \\
\hline Maximum & 9.996706 & 0.509600 & 13.61600 & 0.813000 & $1.10 \mathrm{E}+11$ & 0.193600 \\
\hline Minimum & -4.685541 & 0.000000 & 10.94500 & 0.055000 & $1.53 E+08$ & 0.000200 \\
\hline Std. Dev. & 1.602214 & 0.104120 & 0.671186 & 0.166923 & $2.26 \mathrm{E}+10$ & 0.037894 \\
\hline Skewness & 2.256794 & 3.016409 & -0.586620 & -0.043230 & 2.192321 & 1.803901 \\
\hline Kurtosis & 15.89325 & 11.15114 & 2.568106 & 2.485497 & 7.686589 & 6.355347 \\
\hline Jarque-Bera & 746.4339 & 411.3436 & 6.252094 & 1.088754 & 164.7568 & 97.09833 \\
\hline Probability & 0.000000 & 0.000000 & 0.043891 & 0.580203 & 0.000000 & 0.000000 \\
\hline \multicolumn{7}{|l|}{ Observation } \\
\hline $\mathrm{s}$ & 96 & 96 & 96 & 96 & 96 & 96 \\
\hline
\end{tabular}

Sumber: Output EViews 9, 2017 


\section{Analisis Regresi Data Panel}

Dalam membuat analisis regresi data panel langkah pertama yang harus dilakukan adalah membuat permodelan yang terdiri dari Common Effect, Fixed Effect, dan Random Effect. Kemudian dilakukan uji pemilihan model estimasi regresi data panel terbaik dengan melakukan tiga test yaitu sebagai berikut:

\section{Chow Test/F Test}

Uji ini dilakukan untuk memilih salah satu model pada regresi data panel yaitu antara model Common Effect dan Fixed Effect. Ketentuan yang akan digunakan dalam pengambilan kesimpulan $F$ Test dapat dilakukan sebagai berikut:

a. Jika nilai probabilitas $\mathrm{F}<\mathrm{a}$ (taraf signifikansi/alpha $1 \%, 5 \%$ atau $10 \%$ ) maka $\mathrm{H} 0$ ditolak atau menerima $\mathrm{H} 1$ (Fixed Effect Model).

b. Jika nilai probabilitas $\mathrm{F}>$ a (taraf signifikansi/alpha $1 \%, 5 \%$ atau $10 \%)$ maka HO gagal ditolak (Common Effect Model).

Hipotesis:

H0 : Common Effect Model

\section{$\mathrm{H} 1$ : Fixed Effect Model}

Berikut ini adalah hasil pengujian chow test menggunakan software EViews 9:

Tabel 4.4.

Chow Test

Redundant Fixed Effects Tests

Equation: Untitled

Test cross-section fixed effects

\begin{tabular}{lccc}
\hline Effects Test & Statistic & d.f. & Prob. \\
\hline $\begin{array}{l}\text { Cross-section F } \\
\text { Cross-section }\end{array}$ & 1.851578 & $(31,59)$ & 0.0210 \\
Chi-square & 65.230639 & 31 & 0.0003 \\
\hline
\end{tabular}

Sumber: Output EViews 9, 2017
Berdasarkan hasil chow test pada tabel 4.4. di atas, didapatkan probabilitas $F$ sebesar 0.0210 . hasil chow test menunjukkan bahwa probabilitas $\mathrm{F}<5 \%$ artinya $\mathrm{H} 0$ ditolak dan $\mathrm{H} 1$ diterima, sehingga model yang terbaik menurut chow test adalah fixed effect model.

\section{Hausman Test}

Hausman test dilakukan untuk menguji model terbaik antara Fixed Effect Model dengan Random Effect Model. Dalam penarikan hasil dilakukan dengan membandingkan nilai Fprobabilitas dengan $a$, jika nilai $F-$ probabilitas < a yang ditentukann, maka HO ditolak, dan sebaliknya jika nilai Fprobabilitas > a, maka $\mathrm{HO}$ diterima. Hipotesisnya sebagai berikut:

\section{$\mathrm{HO}:$ Random Effect Model \\ $\mathrm{H} 1$ : Fixed Effect Model}

Berikut ini adalah hasil pengujian hausman test menggunakan software EViews 9:

Tabel 4.5. Hausman Test

Correlated Random Effects - Hausman Test Equation: Untitled

Test cross-section random effects

\begin{tabular}{|c|c|c|c|}
\hline Test Summary & $\begin{array}{c}\text { Chi- } \\
\text { Sq.Statistic }\end{array}$ & $\begin{array}{l}\text { Chi-Sq. } \\
\text { d.f. }\end{array}$ & Prob. \\
\hline $\begin{array}{l}\text { Cross-section } \\
\text { random }\end{array}$ & 16.782689 & 5 & 0.0049 \\
\hline
\end{tabular}

Berdasarkan hasil hausman test pada tabel 4.5. di atas, didapatkan probabilitas $F$ sebesar 0.0049 . hasil hausman test menunjukkan bahwa probabilitas $\mathrm{F}<5 \%$ artinya $\mathrm{H} 0$ ditolak dan $\mathrm{H} 1$ diterima, sehingga model yang terbaik menurut hausman test adalah fixed effect model. 
Berdasarkan hasil chow test dan hausman test di atas diadapatkan model regresi data panel yang sama yaitu fixed effect model lah yang terbaik, sehingga tidak perlu dilakukan Langrage Multiple Test. Berikut adalah Fixed Effect Model:

\section{Tabel 4.6.}

\section{Fixed Effect Model}

Dependent Variable: PERSISTENSI_LABA Method: Panel Least Squares

Sample: 20132015

Periods included: 3

Cross-sections included: 32

Total panel (balanced) observations: 96

Variable Coefficient Std. Error t-Statistic Prob.

\begin{tabular}{|c|c|c|c|c|}
\hline \multicolumn{5}{|l|}{ KEPEMILIKAN } \\
\hline \multicolumn{5}{|l|}{ UKURAN } \\
\hline PERUSAHAAN & -4.878497 & 2.391513 & -2.039920 & 0.0458 \\
\hline LEVERAGE & 7.709793 & 3.034890 & 2.540386 & 0.0137 \\
\hline FEE AUDIT & $6.14 \mathrm{E}-11$ & $1.97 \mathrm{E}-11$ & 3.116757 & \\
\hline PANGSA PASAR & 6.009747 & 19.17681 & 0.313386 & 0.7551 \\
\hline $\mathrm{C}$ & 57.40340 & 29.72134 & 1.931387 & 0.0582 \\
\hline \multicolumn{5}{|c|}{$\begin{array}{l}\text { Effects Specification } \\
\text { Cross-section fixed (dummy variables) }\end{array}$} \\
\hline $\begin{array}{l}\text { R-squared } \\
\text { Adjusted R- }\end{array}$ & 0.532965 & Mean dep & endent var & 0.518407 \\
\hline squared & 0.247995 & S.D. depe & ndent var & 1.602214 \\
\hline S.E. of regression & 1.389411 & Akaike inf & criterion & 3.779660 \\
\hline Sum squared resid & 113.8974 & $\begin{array}{r}\text { Schwarz } \\
\text { Hannar }\end{array}$ & $\begin{array}{l}\text { criterion } \\
\text {-Quinn }\end{array}$ & 4.768002 \\
\hline Log likelihood & -144.4237 & & er. & 4.179164 \\
\hline F-statistic & 1.870248 & Durbin-W & atson stat & 2.337269 \\
\hline Prob(F-statistic) & 0.016062 & & & \\
\hline
\end{tabular}

\section{Uji Asumsi Klasik}

Sebuah model regresi dapat dikatakan baik apabila telah memenuhi uji asumsi klasik, meliputi uji multikolinearitas, uji heterokedastisitas, uji autokorelasi,dan uji normalitas. Untuk melakukan uji asumsi klasik dalam analisis regresi data panel dapat disesuaikan dengan model yang dihasilkan dari pemilihan model. Ketika model yang terbaik menggunkan pndekatan ordinary least square (OLS) maka uji yang dilakukan hanya uji normalitas, uji heterokedastisitas, dan uji autokorelasi.
Berikut akan dilakukan pengujian asumsi klasik pada model yang telah terpilih yaitu Fixed Effect Model sebagai berikut:

\section{Uji Normalitas}

Uji normalitas bertujuan untuk menguji apakah dalam model regresi, variabel pengganggu atau residual memiliki distribusi normal. Seperti diketahui bahwa uji $t$ dan uji $F$ mengasumsikan bahwa nilai residual mengikuti distribusi normal. Jika asumsi ini dilanggar maka uji statistik menjadi tidak valid (Ghozali, 2013). Dalam penelitian ini uji normalitas dilakukan dengan uji Jarque-Bera.

Uji ini mengukur perbedaan skewness dan kurtosis dan menggunakan pengujian statistik (Gujarati dan Porter, 2013). Jika variabel berdistribusi normal maka nilai koefisien skewness $=0$ dan kurtosis $=3$, untuk lebih jelasnya dapat dilakukan dengan melihat nilai JarqueBera dan probabilitasnya. Nilai statistik JB didasarkan pada distribusi normal chisquares dengan derajat kebebasan $(\mathrm{d} f)=$ 2, artinya jika nilai probabilitas $\mathrm{p} J \mathrm{JB}<$ chisquare maka data berdistribusi normal, dan sebaliknya. Disamping itu dapat dilihat dari nilai probabilitas, apabila probability < a, maka tidak berdistribusi normal dan sebaliknya. Berikut adalah hasil uji normalitas menggunakan EViews 9:

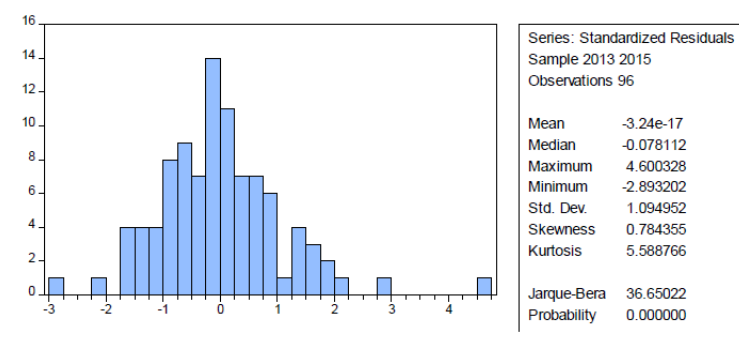

Gambar 4.1.

Uji Normalitas

Sumber: Output EViews 9, 2017 
Berdasarkan gambar di atas diketahui nilai skewness dan kurtosis masing-masing sebesar 0.784355 dan 5.588766. dari nilai skewness dan kurtosis maka dapat disimpulkan bahwa variabel tidak berdistribusi normal karena nilai skewness tidak sama dengan nol dan kurtosis tidak sama dengan tiga. Nilai JB sebesar 36.65022 dan probabilitas sebesar 0.0000 , sedangkan nilai chisquare dengan df 2 dan a 5\% sebesar 5.99, sehingga dapat disimpulkan bahwa data tidak berdistribusi normal karena JB statistik > df 2 atau $36.65022>5.99$, sedangkan probabilitas $\mathrm{p}<$ dari $5 \%$ atau $0.0000<0.05$. Dapat disimpulkan bahwa uji normalitas berdasarkan uji JarqueBera bahwa data residual tidak berdistribusi normal.

Hasil uji asumsi klasik, menunjukkan bahwa model Fixed Effect dinyatakan tidak lulus uji normalitas. Oleh sebab itu dilakukan treatment atau penyembuhan terhadap Fixed Effect Model dengan mentransformasikan model OLS menjadi model GLS, melalui GLS Weight. Sehingga model dapat memenuhi uji asumsi klasik karena model GLS merupakan estimator yang BLUE, Hasil regresi dari tranformasi GLS sebagai berkut:

\section{Tabel 4.7.}

\section{Hasil Regresi GLS Weight}

Dependent Variable: PERSISTENSI_LABA Method: Panel EGLS (Cross-section weights) Sample: 20132015

Periods included: 3

Cross-sections included: 32

Total panel (balanced) observations: 96

Linear estimation after one-step weighting

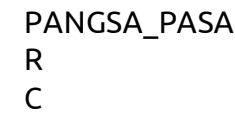

Weighted Statistics

\begin{tabular}{lccc}
\hline $\begin{array}{l}\text { R-squared } \\
\text { Adjusted R- }\end{array}$ & 0.861507 & Mean dependent var & 0.440895 \\
$\begin{array}{l}\text { squared } \\
\text { S.E. of }\end{array}$ & 0.777002 & S.D. dependent var & 2.787859 \\
$\begin{array}{l}\text { regression } \\
\text { F-statistic }\end{array}$ & 1.316895 & Sum squared resid & 102.3185 \\
$\begin{array}{l}\text { Prob(F- } \\
\text { statistic) }\end{array}$ & 10.19481 & Durbin-Watson stat & 2.232796 \\
\hline
\end{tabular}

Model dari hasil regresi GLS Weight di atas merupakan model yang telah dilakukan perbaikan, sehingga model dapat memenuhi uji asumsi klasik, artinya model bersifat BLUE. Dengan demikian, model GLS weight merupakan model yang digunakan dalam penelitian ini, untuk menginterpretasikan uji hipotesis dan penarikan kesimpulan. Berdasarkan tabel di atas, dapat dibuat persamaan matematika regresi data panel sebagai berikut:

\section{$P L_{\text {it }}=38.45322-3.408000 \mathrm{KMit}^{-}$ 3.341775 SIZE $_{\text {it }}+6.529803$ LEV $_{\text {it }}$ + 4.14E-11 FEE $_{\text {it }}+23.76411$ PP $_{\text {it }}$ $+\varepsilon_{\text {it }}$}

Keterangan:

PLit : Persistensi Laba

KMit : Kepemilikan Manajerial

SIZE it : Ukuran Perusahaan

LEV it : Leverage

FEE it : Fee Audit

PPit : Pangsa Pasar

cit : Eror

$\beta 0:$ Konstanta

$\beta 1 \beta 2 \beta 3 \beta 4 \beta 5$ : Koefisien matrix

\begin{tabular}{|c|c|c|c|}
\hline Variable & Coefficient & Std. Error t-Statistic & $\begin{array}{l}\text { Prob. } \\
\text { Uii Signifikansi Simultan (F-test) }\end{array}$ \\
\hline \multicolumn{2}{|l|}{ KEPEMILIKAN } & $9.625605-0.354056$ & ina $F$ test dilakuka \\
\hline UKURAN_PERU & & & apakah semu \\
\hline SAHAAN & -3.341775 & $1.003481-3.330184$ & independen atau bebas yang \\
\hline LEVERAGE & 6.529803 & 1.1708885 .576798 & dimasjukkan dalam model mempunyai \\
\hline FEE_AUDIT & 4.14E-11 & $1.20 \mathrm{E}-113.451582$ & \\
\hline
\end{tabular}


pengaruh secara bersama-sama terhadap variabel dependen. Output uji signifikansi simultan diinterpretasikan dalam tabel 4.8. sebagaimana yang dipaparkan sebelumnya bahwa hipotesis yang diajukan pada uji-F adalah sebagai berikut:

H0: secara bersama-sama variabel independen tidak berpengaruh terhadap variable dependen.

H1: secara bersama-sama variabel independen berpengaruh terhadap variabel dependen.

Tabel 4.8.

Uji Signifikansi Simultan (F-test)

Weighted Statistics

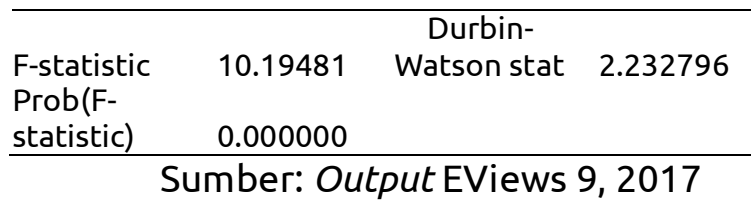

Berdasarkan uji signifikansi simultan di atas diketahui bahwa probabilitas sebesar 0.0000 , artinya probabilitas < signifikansi atau $0.0000<0.05$ maka dapat disimpulkan bahwa $\mathrm{HO}$ ditolak. Sehingga variabel independen secara bersama-sama berpengaruh signifikan terhadap variabel dependen. Artinya variabel independen yang terdiri dari, kepemilikan manajerial, ukuran perusahaan, leverage, fee audit, dan pangsa pasar secara bersama-sama (simultan) mempengaruhi variabel dependen yaitu persistensi laba.

\section{Koefisien Determinasi $\left(\mathbf{R}^{2}\right)$}

Koefisien determinasi $\left(R^{2}\right)$ pada intinya mengukur seberapa jauh kemampuan model dalam menjelaskan variasi variabel dependen yakni persistensi laba. Koefisien determinasi berkisar $0 \leq \mathrm{R}^{2} \leq 1$, artinya jika $\mathrm{R}^{2}=0$ maka tidak ada variabel independen yang dapat menjelaskan variasi variabel dependen. Jika $\mathrm{R}^{2}$ semakin mendekati 1 , berarti menunjukkan semakin kuatnya pengaruh variabel independen terhadap variabel dependen. Interpretasi dari output tabel koefisien determinasi dpat dilakukan dengan menganalisa nila $\mathrm{R}$ Square atau nilai Adjusted R Square, namun beberapa ahli menyarankan dapat dilihat dari Adjusted R Square, hal ini karena dengan menggunakan nilai $R$ Square, nilainya akan berubah jika beberapa variabel independen ditambahkan.

Tabel 4.9.

\section{Koefisien Determinasi}

Weighted Statistics

\begin{tabular}{lccc}
\hline R-squared & 0.861507 & $\begin{array}{c}\text { Mean } \\
\text { dependent var }\end{array}$ & 0.440895 \\
$\begin{array}{l}\text { Adjusted R- } \\
\text { squared }\end{array}$ & 0.777002 & $\begin{array}{c}\text { S.D. dependent } \\
\text { var }\end{array}$ & 2.787859 \\
\hline
\end{tabular}

Sumber: Output EViews 9, 2017

Dari output koefisien determinasi di atas, terlihat bahwa nilai Adjusted R Square adalah sebesar 0.777002 , hal ini menunjukkan bahwa $77.7 \%$ persistensi laba pada perusahaan property dan real estate dipengaruhi oleh variabel kepemilikan manajerial, ukuran perusahaan, leverage, fee audit, dan pangsa pasar, sedangkan 22,3\% dipengaruhi oleh variabel lain yang tidak diteliti. Berdasarkan penelitian terdahulu variabel lain yang mempengaruhi persistensi laba yaitu volatilitas arus kas, volatilitas penjualan dalam penelitian Fanani (2010), besaran akrual (Rahmadhani 2016, Setianingsih 2014), kualitas audit (Juliardi 2013) dan sebagainya. 


\section{Uji Signifikansi Parameter Individual (Uji Statistik t)}

Uji statistik $t$ dilakukan untuk mengetahui seberapa besar pengaruh satu variabel penjelas/independen secara individual dalam menerangkan variasi variabel dependen. Uji signifikansi parsial dilakukan dengan cara membandingkan statistik probabilitas dengan $a$, jika statistik probabilitas < a maka variabel independen berpengaruh secara signifikan pada variabel dependen, sebaliknya jika statistik probabilitas > a maka variabel independen tidak berpengaruh secara signifikan.

Tabel 4.10.

\section{Uji Signifikansi Parameter Individual}

(Uji Statistik t)

Dependent Variable: PERSISTENSI_LABA

Method: Panel EGLS (Cross-section weights)

Sample: 20132015

Periods included: 3

Cross-sections included: 32

Total panel (balanced) observations: 96

Linear estimation after one-step weighting matrix

Variable Coefficient Std. Error t-Statistic Prob.

\begin{tabular}{lcccc}
\hline KEPEMILIKAN & & & & \\
MANAJERIAL & -3.408000 & 9.625605 & -0.354056 & 0.7246 \\
UKURAN_PERUS & & & & \\
AHAAN & -3.341775 & 1.003481 & -3.330184 & 0.0015 \\
LEVERAGE & 6.529803 & 1.170888 & 5.576798 & 0.0000 \\
FEE_AUDIT & $4.14 \mathrm{E}-11$ & $1.20 \mathrm{E}-11$ & 3.451582 & 0.0010 \\
PANGSA_PASAR & 23.76411 & 7.539200 & 3.152073 & 0.0025 \\
C & 38.45322 & 12.71065 & 3.025276 & 0.0037
\end{tabular}

Sumber: Output EViews 9, 2017

Dari tabel di atas maka dapat

diinterpretasikan dalam model persamaan matematik analisis regresi data panel dalam penelitian ini sebagai berikut:

\section{PLit $=38.45322-3.408000$ KMit - 3.341775 SIZEit + 6.529803 LEVit + 4.14E-11 FEEit + 23.76411 PPit + عit}

Berdasarkan uji signifikansi parsial di atas, maka penarikan hipotesis secara parsial dapat disimpulkan sebagai berikut:

1. Hipotesis pertama (H1) variabel kepemilikan manajerial tidak berpengaruh terhadap persistensi laba, yang ditunjukkan dengan nilai probabilitas yang lebih besar dari pada a $5 \%$ (0.7246 > 0.05). Sehingga HO diterima, nilai tersebut menunjukkan bahwa hipotesis yang diajukan sebelumnya ditolak, yaitu suatu variabel independen bukan merupakan variabel penjelas yang signifikan terhadap variabel dependen.

2. Hipotesis kedua $(\mathrm{H} 2)$, variabel ukuran perusahaan berpengaruh negatif secara signifikan terhadap persistensi laba, dengan nilai probabilitas sebesar 0.0015 artinya variabel ukuran perusahaan signifikan pada a $1 \%(0.0015<0.01)$ dengan demikian $\mathrm{H} 0$ ditolak dan $\mathrm{H} 1$ diterima, tetapi arah pengaruh yang ditunjukkan pada variabel ukuran perusahaan tidak sesuai dengan $\mathrm{H} 1$ yang menyatakan bahwa ukuran perusahaan berpengaruh positif terhadap persistensi laba.

3. Hipotesis ketiga (H3), variabel leverage berpengaruh positif secara signifikan terhadap persistensi laba, yang ditunjukkan dengan nilai probabilitas sebesar 0.0000 artinya variabel leverage signifikan pada a $1 \%(0.0000<0.01)$ dengan demikian $\mathrm{H} 0$ ditolak dan $\mathrm{H} 1$ diterima.

4. Hipotesis keempat (H4), variabel fee audit berpengaruh positif secara 
signifikan terhadap persistensi laba, yang ditunjukkan dengan nilai probabilitas sebesar 0.0010 artinya variabel fee audit signifikan pada a $1 \%(0.0010<0.01)$ dengan demikian $\mathrm{H} 0$ ditolak dan $\mathrm{H} 1$ diterima.

5. Hipotesis kelima (H5), variabel pangsa pasar berpengaruh positif secara signifikan terhadap persistensi laba, yang ditunjukkan dengan nilai probabilitas sebesar 0.0025 artinya variabel pangsa pasar signifikan pada a $1 \%(0.0025<0.01)$ dengan demikian $\mathrm{H} 0$ ditolak dan $\mathrm{H} 1$ diterima.

\section{PEMBAHASAN}

\section{Pengaruh Kepemilikan Manajerial Terhadap Persistensi Laba}

Pengujian hipotesis di atas menunjukkan bahwa hipotesis pertama (H1) ditolak dan menerima H0, dengan kata lain variabel kepemilikan manajerial tidak memiliki pengaruh terhadap persistensi laba. Hasil penelitian ini tidak mendukung penelitian dari Agrini (2015), Jumiati dan Ratnadi (2014) bahwa kepemilikan manajerial berpengaruh positif terhadap persistensi laba, artinya semakin besar kepemilikan saham yang dimiliki manajerial semakin tinggi tingkat persistensi laba suatu perusahaan, tetapi penelitian ini mendukung penelitian Nurochman dan Solikhah (2015) yang menyatakan bahwa kepemilikan manajerial tidak berpengaruh terhadap persistensi laba.

Hasil penelitian ini juga mendukung teori agency, yang menyatakan bahwa rendahnya tingkat kepemilikan saham oleh manajemen mengakibatkan kurangnya pihak manajer yang merasa memiliki kepentingan yang sama dengan pemegang saham sehingga laba yang dihasilkan perusahaan kurang persisten karena tingginya tingkat kemungkinan manajer untuk melakukan manipulas angka-angka akuntansi (Jensen dan Meckling, 1976). Hal tersebut dapat dibuktikan dengan melihat data kepemilikan manajerial (dilampirkan), bahwa masih banyak perusahaan property dan real estate yang mempunyai persentase kepemilikan manajerial dibawah rata-rata kepemilikan manajerial tiap tahunnya, bahkan sebagian besar perusahaan property dan real estate mempunyai kepemilikan manajerialnya sebesar $0 \%$. Dengan jumlah presentase yang kecil ini kemampuan manajer untuk melakukan kontrol terhadap perusahaan juga relatif lemah.

\section{Pengaruh Ukuran Perusahaan Terhadap Persistensi Laba}

Pengujian hipotesis untuk ukuran perusahaan di atas menunjukkan bahwa hipotesis pertama ( $\mathrm{H} 1)$ diterima dan menolak $\mathrm{HO}$, dengan kata lain variabel ukuran perusahaan memiliki pengaruh yang signifikan terhadap persistensi laba, tetapi variabel ukuran perusahaan berpengaruh negatif. Hasil penelitian ini tidak mendukung penelitian Malahayati (2015), Nuraini (2014) bahwa ukuran perusahaan berpengaruh positif terhadap persistens laba.

Perusahaan besar yang telah
mencapai tahap kedewasaan
mencerminkan bahwa perusahaan relatif
lebih stabil dan lebih mampu
menghasilkan laba dibandingkan
perusahaan kecil. Bagi perusahaan yang
stabil biasanya tingkat kepastian untuk
memperoleh laba sangat tinggi.
Sebaliknya, bagi perusahaan kecil besar
kemungkinan laba yang diperoleh juga
belum stabil karena tingkat kepastian


laba lebih rendah. Selain itu, perusahaan besar akan memiliki sumber daya yang besar untuk digunakan dalam kegiatan usaha (Yustiana, 2011). Meskipun demikian, perusahaan besar akan banyak menghadapi sensitivitas politik yang tinggi dan menghadapi biaya politis yang lebih tinggi dari pada perusahaan kecil (Gu et al., 2002). Biaya politis diantaranya ialah intervensi pemerintah, pengenaan pajak, dan berbagai macam tuntutan lain. Penelitian ini didukung oleh pernyataan Gu et. al (2002), yang menyatakan bahwa perusahaan besar akan mengurangi biaya politis dengan menggunakan pilihan akuntansi yang dapat mengurangi laba. Dengan begitu laba yang dihasilkan cenderung kecil dan tidak persisten serta tidak mencerminkan kualitas laba yang sesungguhnya yang dihasilkan oleh perusahaan. Sehingga semakin besar ukuran perusahaan akan menurunkan tingkat persistensi laba.

\section{Pengaruh Leverage terhadap Persistensi Laba}

Pengujian hipotesis untuk leverage di atas menunjukkan bahwa hipotesis pertama $(\mathrm{H} 1)$ diterima dan menolak $\mathrm{H} 0$, artinya bahwa leverage berpengaruh positif terhadap persistensi laba. Setiap perusahaan selalu ingin mengembangkan perusahaannya, salah satunya dengan cara menambah utang sebagai tambahan modal. Maka dari itu, ketika perusahaan mempunya tingkat leverage yang tinggi perusahaan akan meningkatkan persistensi laba dengan tujuan untuk mempertahankan kinerja perusahaan yang baik dimata investor. Dengan kinerja yang baik diharapkan kreditor tetap memiliki kepercayaan terhadap perusahaan, tetap mengucurkan dana, dan perusahaan akan memperoleh kemudahan dalam proses pembayaran. Begitu juga kepada investor, perusahan dapat memberikan gambaran kinerja perusahaan, bahwa perusahaan mampu mempertahankan laba di masa mendatang meskipun biaya yang dikeluarkan perusahaa bertambah yaitu biaya bunga atas pinjaman (Rahmadhani, 2016), hal ini sesuai dengan signaling theory, bahwa manjemen atau pihak internal akan memberikan sinyal pada pihak luar, salah satunya berupa informasi keuangan positif dan bisa dipercaya yang akan mengurangi ketidakpastian mengenai prospek di masa depan

Hasil penelitian ini mendukung penelitian yang dilakukan oleh Fanani (2008), dan Rahmadhani (2016), yang menyatakan bahwat tingkat utang perusahaan yang besar akan menyebabkan perusahaan meningkatkan persistensi laba dengan tujuan untuk mempertahankan kinerja perusahaan yang baik di mata kreditor dan investor. Selain itu juga, ketika perusahaan memperoleh penambahan modal dari luar perusahaan yaitu berbentuk utang, maka secara langsung kemampuan perusahaan untuk menghasilkan laba yang persisten bertambah karena tersedianya modal yang cukup.

\section{Pengaruh Fee Audit Terhadap Persistensi Laba}

Pengujian hipotesis untuk fee audit di atas menunjukkan bahwa hipotesis pertama $(\mathrm{H} 1)$ diterima dan menolak $\mathrm{H} 0$, artinya bahwa fee audit berpengaruh positif terhadap persistensi laba, semakin tinggi fee audit yang dibayarkan maka persistensi laba akan semakin meningkat. Hal ini dikarenakan fee audit yang besar dapat mendorong KAP lebih independen karena dengan fee yang besar dapat tersedia dana untuk 
penelitian dan penerapan prosedur audit yang lebih luas dan seksama.

Hasil penelitian ini mendukung hasil penelitian Gammal (2012) membuktikan bahwa perusahaan multinasional dan bank-bank di Lebanon lebih memilih untuk membayar biaya audit yang bernominal besar dengan alasan yaitu mereka lebih mencari auditor dalam kantor akuntan publik yang dapat menghasilkan laporan audit yang berkualitas dan dapat meningkatkan kredibilitas laporan keuangan tahunan yang dapat bersaing diseluruh dunia. Dengan adanya auditor eksternal yang independen dapat mendorong manajemen untuk meningkatkan kinerja salah satunya dengan melaporkan laba yang berkualitas atau laba yang persisten dan mengurangi praktik manjemen laba.

\section{Pengaruh Konsentrasi Pasar Terhadap Persistensi Laba}

Pengujian hipotesis untuk pangsa pasar di atas menunjukkan bahwa hipotesis pertama $(\mathrm{H} 1)$ diterima dan menolak H0, artinya bahwa pangsa pasar berpengaruh positif terhadap persistensi laba, semakin tinggi pangsa pasar yang dimiliki maka persistensi laba akan semakin meningkat. Hal ini dikarenakan, pangsa pasar bersinggungan langsung dengan laba hal tersebut dikarenakan adanya faktor penjualan dalam pangsa pasar. Semakin besar penjualan perusahaan, dan perusahaan dapat mempertahankan penjualan maka akan mempengaruhi laba perusahaan. Jika segmen pasar perusahaan besar perusahaan mempunyai posisi kuat dalam kompetisi sehingga mampu mempertahankan labanya, hal ini sesuai dengan signaling theory bahwa perusahaan akan memberikan sinyal tentang masa depan perusahaan yang lebih baik melalui persistensi labanya.

Hasil penelitian ini mendukung penelitian Fanani (2008) yang menyatakan Konsentrasi pasar menunjukkan pengaruh yang positif dan signifikan terhadap kualitas pelaporan keuangan karena jika segmen pasar perusahaan besar, perusahaan mempunyai posisi kuat dalam kompetisi sehingga perusahaan akan memberikan sinyal tentang masa depan perusahaan yang lebih baik.

\section{Pengaruh Kepemilikan Manajerial, Ukuran Perusahaan, Leverage, Fee Audit, dan Konsentrasi Pasar Terhadap Persistensi Laba}

Berdasarkan hasil uji-F yang telah dijelaskan sebelumnya, kesimpulan yang dapat diperoleh adalah kepemilikan manajerial, ukuran perusahaan, leverage, fee audit, dan konnsentrasi pasar secara bersama-sama (simultan) berpengaruh terhadap persistensi laba. $\mathrm{Hal}$ ini dikarenakan berdasarkan uji signifikansi simultan di atas diketahui bahwa probabilitas sebesar 0.0000 , artinya probabilitas < signifikansi atau $0.0000<$ 0.05 maka dapat disimpulkan bahwa HO ditolak.

\section{PENUTUP}

\section{Kesimpulan}

Dari hasil analisis dan pembahasan yang telah dikemukakan pada bab sebelumnya diperoleh kesimpulan sebagai berikut:

1. Variabel kepemilikan manajerial tidak berpengaruh terhadap persistensi laba, karena rendahnya kepemilikan saham oleh manajemen, menyebabkan kontrol manajemen 
terhadap perusahaan relatif rendah dan adanya kemungkinan manajemen untuk melakukan manajemen laba, sehingga laba yang dilaporkan mempunyai kualitas yang rendah dan cenderung tidak persisten.

2. Variabel ukuran perusahaan berpengaruh negatif terhadap persistensi laba, hal ini dikarenakan perusahaan besar akan mengurangi biaya politis dengan menggunakan pilihan akuntansi yang dapat mengurangi laba. Dengan begitu laba yang dihasilkan cenderung kecil dan tidak persisten serta tidak mencerminkan kualitas laba yang sesungguhnya yang dihasilkan oleh perusahaan.

3. Variabel leverage berpengaruh positif terhadap persistensi laba, hal ini dikarenakan tingkat utang perusahaan yang tinggi akan menyebabkan perusahaan meningkatkan persistensi laba dengan tujuan untuk mempertahankan kinerja perusahaan yang baik di mata kreditor dan investor walaupun biaya yang dikelurkan perusahaan bertambah yaitu biaya bunga pinjaman, serta dengan leverage yang besar secara tidak langsung kemampuan perusahaan untuk menghasilkan laba pun besar karena tersedianya dana yang cukup yaitu dana yang bersumber dari utang.

4. Variabel fee audit berpengaruh positif terhadap persistensi laba, fee audit yang besar dapat mendorong KAP lebih independen karena dengan fee yang besar dapat tersedia dana untuk penelitian dan penerapan prosedur audit yang lebih luas dan seksama, dengan adanya audit eksternal yang independen mendorong manajemen untuk meningkatkan kinerja salah satunya dengan melaporkan laba yang berkualitas atau laba yang persisten dan mengurangi praktik manjemen laba.

5. Variabel konsentrasi pasar berpengaruh positif terhadap persistensi laba, Jika segmen pasar perusahaan besar perusahaan mempunyai posisi kuat dalam kompetisi sehingga mampu mempertahankan labanya, serta adanya faktor penjualan dalam pangsa pasar sehingga apabila perusahaan memiliki penjualan yang besar dan perusahaan dapat mempertahankan penjualan maka akan mempengaruhi laba perusahaan.

6. Variabel kepemilikan manajerial, ukuran perusahaan, leverage, fee audit dan konsentrasi pasar secara simultan berpengaruh terhadap persistensi laba.

\section{Saran}

Berdasarkan kesimpulan dan keterbatasan dari penelitian yang telah dilakukan, penulis memberikan saransaran sebagai berikut:

1. Penelitian selanjutnya dapat mencoba melakukan penelitian dengan periode pengamatan yang lebih lama dalam melakukan penelitian.

2. Penelitian selanjutnya disarankan melakukan penelitian dengan populasi tidak hanya terbatas pada satu jenis perusahaan yaitu perusahaan property dan real estate.

3. Pengaruh kelima variabel masih sangat kecil, oleh karena itu bagi peneliti yang akan meneliti dengan tema yang sama, sebaiknya 
menambah jumlah variabel bebas, agar hasil penelitian dapat lebih baik lagi.

4. Bagi perusahaan, untuk meningkatkan kepercayaan pemegang saham terhadap perusahaan, maka perusahaan harus mampu menunjukkan kinerja perusahaan yang bagus dan menyampaikan informasi yang relevan dan reliabel kepada investor mengenai perkembangan perusahaan, dan persistensi labanya, dengan memperhatikan kepemilikan manajerial, ukuran perusahaan, leverage, fee audit, dan konsentrasi pasar sebagai faktor-faktor yang dapat mempengaruhi persistensi laba.

5. Bagi calon investor dan kreditor, hendaknya sebelum menanamkan modalnya atau memberikan pinjaman pada perusahaan, terlebih dahulu mempertimbangkan persistensi laba dan variabel-variabel yang mempengaruhinya, tidak hanya melihat besarnya laba yang diperoleh perusahaan.

\section{DAFTAR PUSTAKA}

Adiliawan, Novi Budy. 2010. Pengaruh Komponen Arus Kas dan Laba Kotor Terhadap Harga Saham. Skripsi. Fakultas Ekonomi, Universitas Dipenogoro, Semarang.

Ajija.Schochrul R dan Setianto, Rahmat H. 2011. Cara Cerdas menguasai EViews.

Jakarta. Selemba Empat.

Bellovary, J. L., Giacomino, D. E., \& Akers, M. D. (2005). Earnings Quality: It's Time to Measure and Report. The CPA Journal.
Chariri, A dan Ghazali, I. 2007. Teori Akuntansi. Badan Penerbit Universitas Dipenogoro.

Dechow, P.M. dan I. Dichev. 2002. "The Quality of Accruals and Earnings: The Role of Accrual Estimation Errors". The Accounting Review 77. Supplement: 35-59.

Demsetz, H, and K Lehn. 1985. The Structure of Corporate Ownership : Causes and Consequences. Journal Political Economy Vol. 9. pp. 1155-1177.

Devi, Ni Putu Yunita dan Erawati, Ni Made Adi. 2014. Pengaruh Kepemilikan Manajerial, Leverage, dan Ukuran Perusahaan Pada Kebijakan Deviden Perusahaan Manufaktur. E-Jurnal Akuntansi Universitas Udayana, Bali.

Djamaluddin, S.H.T. Wulandari, dan Rahmawati, 2008. Analisis perbedaan antara Laba Akuntansi dan Laba Fiskal terhadap Persistensi Laba, Akrual dan Aliran Kas pada Perusahaan Perbankan yang terdaftar di Bursa Efek Jakarta. Jurnal Riset Akuntansi Indonesia, Vol. 11, Hal. 53-74.

Easton, D.P., and Mark, E.Z. 1989. Cross Sectional Variation in Stock Market Response to Accounting Earnings Announcements. Journal of Accounting and Economics 11(1):117141.

Eskananda, Mahyus . 2014. Analisis Ekonometrika Data Panel. Jakarta: Mitra Wacana Media.

Faisal. 2005. Analisis Agency Cost, Struktur Kepemilikan dan Mekanisme Corporate Governance. JRAI Vol 8 No. 22005.

Fajri, Sri Nurul. 2013. Pengaruh Ukuran Perusahaan, Struktur Kepemilikan Dan Konsentrasi Pasar Terhadap Kualitas Laporan Keuangan. Jurnal Fakultas Ekonomi Negeri Padang.

Fanani, Zaenal. 2010. Analisis Faktor Faktor Penentu Persistensi Laba. Jurnal 
Akuntansi dan Keuangan Indonesia Volume 7 - No.1.

Fanani, Zaenal. Ningsih, Sri. Dan Hamidah. 2008. Faktor-faktor Penentu Kualitas Pelaporan Keuangan dan Kepercayaan Investor. Universitas Airlangga. Indonesia.

Fitria, Annisa Ayu. 2013. Pengaruh Kualitas Audit Terhadap Manajemen Laba Dengan Fee Audit Sebagai Variabel Intervening (Studi Empiris pada

Perusahaan Manufaktur yang Terdaftar di Bursa Efek Indonesia (BEI) Tahun 2009-2011). Skripsi. Universitas Islam Negeri Syarif Hidayatullah Jakarta.

Francis, J. R., R. LaFond, P. Olsson, dan K. Schipper. 2004. Costs of Equity and Earnings Attribute. The Accounting Review. Vol.79. No.4: 967-1010.

Ghozali, Imam. Dan Dwi, Ratmono. 2013. Analisis Multivariat dan Ekonometrika, Teori, Konsep, dan Aplikasi dengan EViews 8. Universitas Dipenogoro Semarang.

Godfrey, Jayne; Allan Hodgson; and Scott Holmes, Accounting Theory. Brisbane; Jhon Wiley \& Sons, 1997.

Gu. Z., C.J Lee, and J.G. Rosett. 2002. Information Environment and Accrual Volatility. Working Paper. A. B. Freeman School of Business, Tulane University.

Gujarati, Damodar N dan Porter. 2013. Dasardasar Ekonometrika Buku 1. Jakarta Selemba Empat.

Hanlon, Michelle. 2005. The Persistence and Pricing of Earnings, Accrual, and Cash Flows When Firms Have Large BookTax Differences. The Accounting Review. 80:Pp:137-166.

Hansen, Don. R. dan M. Mowen, Mayane. 2001. Manajemen Biasa Akuntansi dan Pengendalian. Buku Dua. Edisi Kesatu. Jakarta. Selemba Empat.

Harahap, Sofyan Syafari. 2012. Teori Akuntansi Edisi Revisi 2011. PT Rajagrafindo Persada, Jakarta.
Hayn, C. (1995). The Information Content of Losse. Journal of Accounting and Economics, 20, 125-153.

Ikatan Akuntan Indonesia. 2015. Pernyataan Standar Akuntansi Keuangan No.1 2015.

Institut Akuntan Publik Indonesia. 2016. Peraturan Pengurus No.2 tentang Penentuan Imbalan Jasa Audit Laporan Keuangan.

Jensen, Michael, C., and W.H. Meckling. 1976. The Theory of Firm: Managing Behavior, Agency Cost and Ownership Structure, Journal of Financial Economic.

Juliardi, Dodik. 2013. Pengaruh Leverage Konsentrasi Kepemilikan dan Kualitas Audit Terhadap Nilai Perusahaan Serta Laba Persisten Pada Perusahaan

- Perusahaan Publik Manufaktur Yang Listed di Bursa Efek Indonesia (Studi Perbandingan antara PerusahaanPerusahaan Manufaktur yang Diaudit KAP 4 Besar dan KAP Non 4 Besar. Jurnal Akuntansi Aktual Vol. 2 Nomor 2 Juni 2013 hlm 113-122.

Jumiati, Fitria dan Ni Made Dwi Ratnadi, 2014, Pengaruh Kepemilikan Manajerial dan Book Tax Differences Pada Persistensi Laba. E-Jurnal Akuntansi. Universitas Udayana.

Kormendi,R., and Robert,L. 1987. Earning Innovations, Earning Persistance, and Stock Returns. Journal of Bussiness. Vol. 60 (3).

Kurniasih, Margi dan Abdul Rohman. (2014). Pengaruh Audit Fee Audit, Audit Tenure, dan Rotasi Audit Terhadap Kualitas Audit. Diponegoro Journal Of Accounting Volume 3, Nomor 3, Tahun 2014.

Machfoedz, Mas'ud. (1999). Financial Ratio Analysis and The Prediction of Earning Change In Indonesia. Kelola: Gajah Mada University Business Review, no.7/III/1999. 
Malahayati, Rina. Arfan dan Hasan, Basri. 2015.Pengaruh Ukuran Perusahaan Dan Financial Leverage Terhadap Persistensi Laba, Dan Dampaknya Terhadap Kualitas Laba (Studi pada Perusahaan yang Terdaftar di Jakarta Islamic Index). Jurnal Magister Akuntansi ISSN 2302-0164. Pascasarjana Universitas Syiah Kuala.

Mohd. Zdulhiyanov, 2015. Pengaruh Book Tax Differences Terhadap Persistensi Laba (Studi Empiris Pada Perusahaan Manufaktur yang Terdaftar di Bursa Efek Indonesia Tahun 2008-2011). Artikel Ilmiah, Universitas Negeri Padang.

Novitasari, F. 2004. Analisis Faktor-Faktor Yang Mempengaruhi Independensi Auditor. Skripsi. Universitas Katolik Soegijapranata. Semarang.

Nugroho, Deffa Agung. 2012. Pengaruh Struktur Kepemilikan Manajerial, Debt Covenant, Tingkat Kesulitan Keuangan Perusahaa, Dan Risiko Litigasi Terhadap Konservatisme Akuntansi (Studi Empiris Pada Perusahaan Manufaktur Yang Terdaftar di BEI Tahun 2008-2010). Skripsi. Universitas Dipenogoro, Semarang.

Nuraini, Mety. 2014. Analisis Faktor-Faktor Penentu Persistensi Laba. Skripsi.

Semarang: Universitas Diponegoro.

Nurochman, Afid. Dan Solikhah, Badingatus. 2015. Pengaruh Good Corporate Governance, Tingkat Hutang Dan Ukuran Perusahaan Terhadap

Persistensi Laba. Accounting Analysis Journal.

http://journal.unnes.ac.id/sju/index.php/aaj

Nuswantara, D.A. 2004. The Effect of Market Share and Leverage Interaction Toward Earnings Management Practices. Makalah. SNA VII. Bali: 170185.

Panjaitan, Yunia, Dewinta Oky dan K, Sri Desinta. 2004. Analisis Harga Saham,
Ukuran Perusahaan, dan Risiko Terhadap Return yang Dlharapkan Investor Pada Perusahaan Saham Aktif. Balance

Paton, W.A. dann A.C. Littleton. An Introduction to Corporate Accounting Standard. Ann Arbor: American Accounting Association, 1970.

Penman, S.H. 2001. On Comparing Cash Flow and Accrual Accounting Models For Use in Equity Valuation. Working paper, www.ssrn.com

Persada, Aulia Eka dan Martani, Dwi. 2010. Analisis Faktor yang Mempengaruhi Book Tax Gap dan pengaruhnya terhadap Persistensi Laba. Jurnal Akuntansi dan Keuangan Indonesia. Volume 7- No.2. Desember 2010. ISSN: 2406-9701.

Purwanti, Sheila Nika., Hardi dan Mudrika Alamsyah Hasan. 2013. Pengaruh Perbedaan antara Laba Akuntansi dan Laba Fiskal terhadap Persistensi Laba pada Perusahaan yang Listing di Bursa Efek Indonesia. Repository Universitas Riau.

Putra, Surya Andhika. 2013. Analisis Pengaruh Ukuran Perusahaan, Kepemilikan Institusional, dan Kepemilikan Manajerial Terhadap Kinerja Perusahaan Serta Dampaknya Terhadap Nilai Perusahaan (Studi terhadap Perusahaan Manufaktur Yang Terdaftar di BEI Tahun 20072011). Skripsi. Universitas Dipenogoro. Semarang.

Romasari, Sonya. 2013. Pengaruh Persistensi Laba, Struktur Modal, Ukuran Perusahaan dan Alokasi Pajak Antar Periode Terhadap Kualitas Laba (Studi Empiris pada Perusahaan Manufaktur yang Terdaftar di BEI). Skripsi. Padang: Universitas Negeri Padang.

Rusdianti, Rani. 2014. Pengaruh Corporate Governance dan Karakteristik Perusahaan Terhadap Ketepatan Waktu Pelaporan Perusahaan di Internet (Corporate Internet Reporting 
Timeliness). Jurnal. Fakultas Ekonomi Universitas Negeri Surabaya.

Rustiarini, Ni Wayan. 2011. Pengaruh Struktur Kepemilikan Saham Pada Pengungkapan Corporate Social Responsibility. Audit Jurnal Akuntansi dan Bisnis, 12 (1) : 1-12.

Schipper, K. and L. Vincent. 2003. Earnings Quality. Accounting Horizons. Vol.70.

Supplement: 97-110.

Septavita, Nurul. 2016. Pengaruh Book Tax Differences, Arus Kas Operasi, Tingkat Hutang, Dan Ukuran Perusahaan Terhadap Persistensi Laba. JOM Fekon, Vol.3 No.1 (Februari) 2016.

Sholikhati dkk. 2015. Pengaruh Book Tax Differences dan Kepemilikan Mayoritas terhadap Persistensi Laba dan Reaksi Pasar pada Perusahaan Manufaktur Tahun 2011-2013. Universitas Trunojoyo Madura.

Subramanyam, K.R ,John J .Wild. 2014. Analisa Laporan Keuangan. Edisi Kesepuluh, Buku Dua. Jakarta: Salemba Empat.

Sudarmadji, Ardi Murdoko dan Sularto, Lana. 2007. Pengaruh Ukuran Perusahaan, Profitabilitas, Leverage, dan Tipe Kepemilikan Perusahaan Terhadap Luas Voluntary Disclosure Laporan Keuangan Tahunan. Proceeding PESAT Vol.2. Auditorium Kampus Gunadarma.

Sugiyono. 2016. Metode Penelitian Kuantitatif, Kualitatif, dan R\&D. Alfabeta, Bandung.

Sukrisno Agoes. 2012. Auditing Petunjuk Praktis Pemeriksaan Akuntan Oleh Akuntan Publik. Salemba Empat. Jakarta

Suwandika, I.M.A., \& Astika, I.B.P. (2013).Pengaruh Perbedaan Laba Akuntansi, Laba Fiskal, Tingkat Hutang pada Persistensi Laba. EJurnal Akuntansi Universitas Udayana, 5(1), 196 - 214.
Suwardjono. 2013. Teori Akuntansi Perekayasaan Pelaporan Keuangan Edisi Ketiga. BPFE-Yogyakarta.

Tandiontong, Mathius. 2016. Kualitas Audit Dan Pengukurannya. Alfabeta, Bandung.

Tarigan, Josua dan Yulius Jogi Christiawan. 2007. Kepemilikan Manajerial, Kebijakan Hutang, Kinerja, Dan Nilai Perusahaan. Fakultas Ekonomi Universitas Kristen Petra. Jurnal Akuntansi Dan Keuangan., Vol. 9. No.1, Mei 2007: Hal. 1-8.

Taures, Nazila Sofi Istna. 2011. Analisis Hubungan antara Karakteristik Perusahaan dengan Pengungkapan Resiko. Skripsi, Universitas Diponegoro.

Tedjosukmono, Shannon Dorothy. dan Juniarti. 2016. Pengaruh Kinerja Corporate Social Responsibility (CSr) Terhadap Persistensi Laba Pada Perusahaan Yang Bergerak Di Sektor Industri Dasar Dan Kimia Di Indonesia. 350 Business Accounting Review Vol. 4, No. 1, Januari 2016 (349-360).

Tumirin. 2003. Analisis Variabel Akuntansi Kuartalan, Variabel Pasar, Arus Kas Operasi Yang Mempengaruhi Bid-Ask Speread. Thesis. Program Pascasarjana Universitas Gajah Mada.

Undang-undang Republik Indonesia Nomor 20. Tahun 2008. Tentang Usaha Mikro, Kecil dan Menengah.

Watts, Ross L. dan Jerold L. Zimmerman. 1986. Positive Accounting Theory, Englewood Cliefs, New Jersey: Prentice-Hall., Inc.

Widarjono, Agus. 2013. Ekonometrika : Pengantar dan Aplikasinya. Yogyakarta.

Uppm Stim. Ykpn.

Wijayanti, H.T., 2006, Analisis Pengaruh Perbedaan antara Laba Akuntansi dan Laba Fiskal terhadap Persistensi Laba, Akrual, dan Arus Kas, Simposium Nasional Akuntansi IX, Padang. 
Winarmo, Wing Wahyu. 2009. Analisis Ekonometrika dan Statistika. Yogyakarta.

Sekolah Tinggi Ilmu Manajemen. Ykpn.

http://investasi.kontan.co.id/news/kinerjaemiten-properti-kurangmentereng, (diakses: 10, Mei 2017 pukul: 20.00 WIB).

http://www.cnnindonesia.com/ekonomi/201 50403111717-92-44043/usai-terjeratkasus-suap-laba-sentul-city-turun9326-persen/ (Diakses: 16 Februari 2017 pukul: 19.00).

http://www.indonesiainvestments.com/id/berita/kolomberita/analisis-pasarpropertiindonesia-overview-kepemilikanasing/item5728, (diakses: 5, Mei 2017 pukul: 08.43 WIB). http://www.kembar.pro/2015/09/melihatpeluang-dan-kendala-bisnis-propertidiindonesia.html, (diakses: 10, Mei 2017 pukul: 21.30 WIB).

https://ekbis.sindonews.com/read/847842/3 2/laba-modernland-2013-meroket841-1395821432 (Diakses: 2 Februari 2017 pukul: 19.00).

https://ekbis.sindonews.com/read/861351/3 2/laba-bersih-plaza-indonesia-anjlok858-1399460607 (Diakses: 2 Februari 2017 pukul: 21.00).

www.idx.com (diakses: 5 Maret 2017 pukul:10.00 WIB)

www.sahamok.com (diakses: 5 Maret 2017 pukul: 09.00 WIB) 